Article

\title{
Entrepreneurial Competence: Using Machine Learning to Classify Entrepreneurs
}

\author{
Clariandys Rivera-Kempis ${ }^{1, *,+(\mathbb{D}, \text { Leobardo Valera }}{ }^{2,+}+$ and Miguel A. Sastre-Castillo ${ }^{3,+}+\mathbb{C}$ \\ 1 Centro de Emprendedores, Instituto de Estudios Superiores de Administración (IESA), \\ Caracas 1011, Venezuela \\ 2 Department of Electrical Engineering and Computer and Science, University of Tennessee Knoxville, \\ Knoxville, TN 37996, USA; lvalera@utk.edu \\ 3 Faculty of Commerce and Tourism, Universidad Complutense de Madrid, 28003 Madrid, Spain; \\ masastre@ucm.es \\ * Correspondence: clariandys.rivera@iesa.edu.ve \\ + These authors contributed equally to this work.
}

Citation: Rivera-Kempis, C.; Valera, L.; Sastre-Castillo, M. Entrepreneurial Competencies: Using Machine Learning to Classify Entrepreneurs. Sustainability 2021, 13, 8252.

https://doi.org/10.3390/su13158252

Academic Editor: Miguel-Ángel

Galindo-Martín

Received: 6 May 2021

Accepted: 19 July 2021

Published: 23 July 2021

Publisher's Note: MDPI stays neutral with regard to jurisdictional claims in published maps and institutional affiliations.

Copyright: (c) 2021 by the authors. Licensee MDPI, Basel, Switzerland. This article is an open access article distributed under the terms and conditions of the Creative Commons Attribution (CC BY) license (https:/ / creativecommons.org/licenses/by/ $4.0 /)$.

\begin{abstract}
Competencies are behaviors that some people master better than others, which makes them more effective in a given situation. Considering that entrepreneurship translates into behaviors, the competency-based approach expresses attributes necessary in the generation of such behaviors with greater precision. By virtue of the dynamic and complicated nature of entrepreneurial phenomena and, especially, of the numerous data sets and variables that accompany the entrepreneur, it has become increasingly difficult to characterize it. In this study, we use predictive analysis from the machine learning approach (unsupervised learning) in order to determine if the individual is an entrepreneur, based on measures of 20 attributes of entrepreneurial competence relative to classification and ranking. We investigated this relationship using a sample of 6649 individuals from the Latin American context and a series of algorithms that include the following: logistic regression, principal component analysis, ranking and classification of data using the Ward method, linear discriminant analysis, and Gaussian regression among others.
\end{abstract}

Keywords: entrepreneurship; entrepreneur; entrepreneurial competence; machine learning; logistic regression; linear discriminant; hierarchical agglomerative clustering algorithm

\section{Introduction}

Since the study of entrepreneurship began approximately 250 years ago, academics from different disciplines have provided a series of interpretations and definitions to conceptualize the study, which results in obtaining different approaches to the topic. Its use began during the second half of the 18th century and the beginning of the 19th century with the economists Richard Cantillon [1] and Jean Baptiste Say [2], who were not only concerned with the economy in macro terms but also with companies and creation and new business management. The fact is that they both viewed entrepreneurs as risk-takers in investing their own money [3]. Since then, it is likely that entrepreneurs constitute one of the most widely studied population groups with the greatest heterogeneity.

The notion that entrepreneurs were somehow different from the rest of the population provided the impetus for significant research on the subject during the 1960s and 1970s [4]. However, until Herron [5] demonstrated that entrepreneurial prowess and its tendencies are related to the performance of the new business, the persistent attempts of researchers aligned with linking the attributes of the entrepreneurial individual in the performance of the new business [6,7] resulted in little success.

Although some have argued that the search for differences or individual characteristics should be abandoned in favor of research that focuses on the external causes that generate entrepreneurial behavior [8-10], in recent decades, attention has focused on how the 
performance of the business itself is influenced by the entrepreneur [11,12]. That is why the literature presents a large number of definitions of entrepreneurship associated with the entrepreneur's behavior as a key element in the process.

From the conclusions and future lines of research proposed by some authors [13-17], there is a need to orient entrepreneurship research towards the level of individual analysis, either from the study of psychological and sociological aspects or from the behaviors necessary to start the entrepreneurial process that result in creating a new business.

The entrepreneur plays a decisive role in relevant decisions related to business creation and transformation, its relevance is manifested in the different schools of thought relative to entrepreneurship [18]. There are pioneering works that emphasize the characteristics of entrepreneurs and their value in the creation of a company and many authors point out that entrepreneurial behavior depends on the attributes of the individual, among which includes the following: tolerance to failure and uncertainty [19]; leadership [20]; self-efficacy [21,22]; tendency to take risks [23,24]; decision making and problem solving [15,25], among others. It is the combination of these attributes among others that result in business creation.

This study assumes that entrepreneurs are essential in business creation and will focus on the characteristics that, according to the review carried out, are considered necessary in entrepreneurial behavior. That is why this work focuses on the application of the Kempem Model, which is aimed at measuring and analyzing the 20 attributes that make up entrepreneurial competence in the three following dimensions: knowledge (knowing how to know), skills (knowing how to do), and attitudes and values (knowing how to be and knowing how to live together) [26-31].

During the past century, small companies were not considered as the drivers of economic growth or employment because such a title seemed reserved for large corporations, which took advantage of their economies of scale to achieve greater competitiveness. Small businesses, however, are closer to their customers, use local resources, generate local employment, and therefore are a source of local development and more compatible with an economic model of sustainable development. The great development of information and communication technologies, with the Internet as the protagonist, rendered knowledge a serious competitor relative to capital in terms of productivity. When innovative business initiatives took this knowledge to transform it into value-generating products and services, the "new economy" emerged and, since then, entrepreneurship became more relevant as a source of sustainable economic growth.

The main contribution on this paper is to establish the basis for the conception of entrepreneurship as a competence and to achieve a comprehensive definition based on the entrepreneur that is in harmony with the requirements of the European Higher Education Area (EHEA) [32,33] and world trends [30,34-37]. Additionally, it constitutes an effort to provide context and quantification in all possible areas for a requirement of today's society such as entrepreneurship and the analysis of the entrepreneurial attributes manifested through entrepreneurial competence. All this is aimed at designing new models for the identification, classification and hierarchy of entrepreneurs, key activities for educational organizations, government, multilateral entities, capitalists, and investors and companies by using machine learning tools to design programs that address the gaps detected and to make a better selection of the entrepreneurs they support by considering their knowledge, skills, attitudes, and values in order to reduce the search costs and risks associated with selection and in order to significantly increase the economic and social impact on countries.

\section{Theoretical Framework}

The notion of competence has been around for centuries. For example, in medieval guilds, apprentices worked with a teacher and received certificates when their work reached the standard established in the activity they performed. In business, competence models are based on various approaches and notions of the concept. The human element acquires a fundamental role in today's successful company. 
In the sixties of the twentieth century, David McClelland began research from Harvard University where he expressed that academic records, that is, tests on knowledge content, intelligence, and personality tests did not provide useful information to predict reliably the performance of people in different jobs, or to predict their success in levels or professional careers. In this context, McClelland [38] adopted the term competence as an alternative or complementary unit of measure to elucidate these issues. For him, competencies are more related to performance.

McClelland [38] proposed the concept of competence to identify variables that predicted job performance. The differentiating element of the concept and of its own methodology implied addressing the difficulties that people have when reaching the goals that have been proposed. This author bases his research on studies on motivation, the image that the person has of himself, the manner in which he faces the reality of his daily life, the identification and problem-solving strategies that he uses on a daily basis, and the manner in which he manages his interpersonal relationships. Additionally, he proposes to use criteria sampling that involves theory and practice. This requires new psychological skills that are not commonly in the traditional examiner's repertoire. It is about the revision of the role of the examiner or psychologist by changing the tests of word games and statistical analysis for a behavioral analysis.

Competence is knowledge in action. "Knowledge's" immediate meaning is not to describe reality but to modify it and not to define problems but to solve them; in this sense, it is not only knowing what but also knowing how. Competence is conceived as the effective capacity to successfully carry out a fully identified activity that is developed through learning experiences, for which, relative to the field of knowledge, three types of knowledge are integrated: conceptual (knowing how to know), procedural (knowing how to do), and attitudinal (knowing how to be and knowing how to live together) [39].

Competence is defined as an underlying characteristic in the individual that is causally related to a standard of effectiveness and/or superior performance in a job or situation [40]. They are repertoires of behaviors that some people master better than others, which makes them effective in their performance [41]. competence involves the ability to successfully meet complex demands in a particular context. Competence performance or effective action is associated with the mobilization of knowledge, cognitive and practical skills, and other social and behavioral components such as attitudes, emotions, values, and motivations [32]. The competence involves complex processes that people place into action-action-creation to solve problems and carry out activities of daily life and the work or professional context by contributing to the construction and transformation of reality; here, they integrate knowing how to be, knowing how to know, and knowing how to do by taking into account the specific requirements of the environment [30]. This is not a simple procedural of doing as taking its dimensions (knowledge, skills, attitudes and values) separately distorts the multidimensional approach of the competence [42].

In this sense, the Tuning Educational Structures In Europe [33] indicates that the concept of competence maintains an integration-oriented approach since it considers that capabilities are combined with a series of attributes and their interactions allow competent performance. It is stated that competence can convey what the person is capable of doing or what he is competent of executing, as well as the degree of preparation, sufficiency, or responsibility they possess to carry out certain tasks.

As can be observed, in the literature there is a diversity of concepts and criteria in relation to the word competence. That is why the term appears in many areas and with different meanings. Each scenario requires specific competencies, which is why a large number of definitions are found. However, the aforementioned definitions allow the establishment of some fundamental aspects of competence, such as the following:

- It differs from terms such as ability, dexterity, aptitude, capacity, and performance.

- It considers the integration of three elements: knowledge, skills, and attitudes and values.

- Its ideal performance depends on the context where it takes place (knowing how to do it in a context). 
- It covers knowing how to know, how to do, how to be, and how to live together.

- It is not limited only to the behaviors or behaviors observed.

- It is defined in terms of knowing how to act and not knowing how to do, knowing how to know, or knowing how to be separately.

- It is definable in action, as it exists for something that can be performed with it.

- It is perfectly evaluable and measurable.

- It can be learned and developed.

- It implies actions and results.

- It has different levels of performance and different degrees of integration and mastery.

- Involves performing relatively new or non-routine tasks.

- It involves capabilities without which it is not possible to be competent.

- It is flexible and dynamic.

From what has been outlined above, it follows that competence should not only be approached as an observable behavior or behaviors, but that it is the dynamic and comprehensive combination of various attributes grouped in three dimensions (knowledge, skills, and attitudes and values), which allows ideal performance in heterogeneous contexts.

Considering the above, the definitions of the dimensions that will be used in this article and in the methodology developed and applied later are the following [30,39,43,44].

Knowledge: The ability to mentally represent sets of data, facts, concepts, notions, information, propositions, and categories acquired in one or more disciplines through experiences or learning that are necessary for adequate performance.

Skills: The ability to act and intervene in reality through the use of procedures or processes that are necessary for the ideal performance in any activity, whether physical or mental.

Attitudes and values: Attitudes and values consists of the disposition and motivation of the individual to action and the implementation of values in professional and life situations that is based on their autonomy, self-esteem, and ethical life project. In addition, it corresponds to the system of beliefs and stable effective dispositions that the person assumes as referential guidelines to act in a certain way.

On the other hand, it is appropriate to point out that in the field of entrepreneurship, how relevant business opportunities are in terms of its availability to all individuals and their identification and exploitation depend on personal characteristics [45]. Opportunities are there for everyone, but it is not sufficient just to identify them. In order to be considered an entrepreneur, it is also necessary to exploit them and the latter is a decision that only some, for various reasons, choose and based on them create a company. Shane and Venkataraman [46] affirm that for entrepreneurship to arise, two elements must coexist: an opportunity and an individual willing to exploit it.

Many authors state that research on entrepreneurship is increasingly concentrating on the behavior-based approach [13-16,47-49]. Previous research indicates that the study of the attributes of entrepreneurs constitutes a key element within the phenomena of entrepreneurship, which has generated the need to investigate, study, and measure the dominant attributes in entrepreneurs [46,50-54].

In this article, entrepreneurial competence is defined as the following: The individual condition integrated by the ideal combination of knowledge, skills, attitudes and values that determine and are manifested through the implementation of a series of contextualized behaviors oriented to the creation of sustainable companies that is generated from taking advantage of lucrative opportunities for the entrepreneur and competitive for the various actors involved [26-31].

To provide content to this definition and considering the existence of pioneering works that emphasize the characteristics of entrepreneurs and their value in the creation of companies [24,44,46,47,49,52,55], a bibliographic review was carried out focused on the characteristics mostly studied in the last 80 years and that are considered necessary for the entrepreneurial behavior to be generated. Given the lack of consensus and heterogeneity 
in this group, the 20 attributes considered most important in the literature review and for the purposes of this study were integrated and collected in this research.

In Table 1, the attributes of the entrepreneur and their main reference authors are presented.

Table 1. Entrepreneur attributes. Prepared by the authors on the basis of [4,13-25,46-133].

\begin{tabular}{|c|c|}
\hline Attribute & Authors for Reference \\
\hline Autonomous Learning & $\begin{array}{l}\text { Neisser, 1976; Gartner, 1988; Mitchell, Smith, Morse, Seawright, Peredo y Mckenzie, 2002; Politis, 2005; Cope, 2011; } \\
\text { Cannavacciuolo, Iandoli, Ponsiglione y Zollo, 2017. }\end{array}$ \\
\hline Seize opportunities & $\begin{array}{l}\text { Schumpeter, 1982; Begley y Boyd, 1987; Mitton, 1989; Shane y Venkataraman, 2000; Álvarez y Busenitz, 2001; Politis, } \\
\text { 2005; Alvarez y Barney 2007; Welpe, Spörrle, Grichnik, Michl y Audretsch, 2012; Alvarez, Barney y Anderson, 2013; } \\
\text { Davidsson, 2015; Gaglio y Winter, 201. }\end{array}$ \\
\hline Self-efficacy & $\begin{array}{l}\text { Bandura, 1977; Bandura, 1982; Clement, 1987; Herron y Sapienza, 1992; Shane y Venkataraman, 2000; Chen, Gully y } \\
\text { Eden, 2004; Goel y Karri, 2006; McGee, Peterson, Mueller y Sequeira, 2009; Drnovšek, Wincent y Cardon, 2010; } \\
\text { Ahlin, Drnovšek y Hisrich, 2014; Chatterjee y Das, 2015; McGee y Peterson, 2019. }\end{array}$ \\
\hline Thoug & $\begin{array}{l}\text { Neisser, 1976; Shaver y Scott, 1991; Bird, 1992; Krueger, 1993; McGrath, 1999; Shane y Venkataraman, 2000; Álvarez } \\
\text { y Busenitz, 2001; Mitchell, Smith, Morse, Seawright, Peredo y McKenzie, 2002; Baron, 2004; Sommer y Haug, 2011; } \\
\text { Brännback y Carsrud, 2016. }\end{array}$ \\
\hline Competitiveness & $\begin{array}{l}\text { Friedman y Rosenman, 1974; Begley y Boyd, 1987; Matlay, Dinis, Do Paco, Ferreira, Raposo, y Gouveia Rodrigues, } \\
\text { 2013; Stroe, Wincent y Parida, 2018. }\end{array}$ \\
\hline Legitimacy & $\begin{array}{l}\text { Mitton, 1989; Politis, 2005; Tornikoski y Newbert, 2007; Rutherford, Buller y Stebbins, 2009; Kuratko, Fisher, } \\
\text { Bloodgood y Hornsby, 2017. }\end{array}$ \\
\hline Creativity and & $\begin{array}{l}\text { Brockhaus, 1980; Schumpeter, 1982; Gartner, 1988; Cunningham y Lischeron, 1991; Álvarez y Barney, 2001; Cuervo, } \\
\text { 2005; Goel y Karri, 2006; Fillis y Rentschler, 2010; Sarri, Bakouros, y Petridou, 2010; Ahlin, Drnovšek y Hisrich, } \\
\text { 2014; Gundry, Ofstein, y Kickul, 2014; Aldrich y Martinez, 2015; Chatterjee y Das, 2015; Edwards-Schachter, } \\
\text { García-Granero, Sánchez-Barrioluengo, Quesada-Pineda y Amara, 2015. }\end{array}$ \\
\hline Network devel & $\begin{array}{l}\text { Mitton, 1989; Cunningham y Lischeron, 1991; Arenius y De Clercq, 2005; Peris, Peris-Ortiz y Gil-Pechuan, 2010; } \\
\text { Cannavacciuolo, Iandoli, Ponsiglione y Zollo, } 2017 .\end{array}$ \\
\hline Confidence & $\begin{array}{l}\text { Shane y Venkataraman, 2000; Goel y Karri, 2006; Cacciotti y Hayton, 2015; Chatterjee y Das, 2015; Invernizzi, } \\
\text { Menozzi, Passarani, Patton y Viglia, 2017; Bernoster, Rietveld, Thurik, y Torrés, } 2018 .\end{array}$ \\
\hline Previous e & $\begin{array}{l}\text { Schumpeter, 1982; Gartner, 1985; McGrath, 1999; Shane y Venkataraman, 2000; Shepherd, Douglas y Shanley, 2000; } \\
\text { Sarasvathy, 2001; Shane, 2003; Ucbasaran, Westhead y Wright, 2003; Politis, } 2005 .\end{array}$ \\
\hline $\begin{array}{l}\text { Nonconform } \\
\text { ualism }\end{array}$ & $\begin{array}{l}\text { Cunningham y Lischeron, 1991; Goel y Karri, 2006; Anderson y Smith, 2007; Chatterjee y Das, 2015; Liñán, Moriano } \\
\text { y Jaén, 2016. }\end{array}$ \\
\hline Leadership & Fiedler, 1966; Cunningham y Lischeron, 1991; Gupta, MacMillan y Surie 2004; Covin y Slevin, 2015. \\
\hline Internal locus of control & $\begin{array}{l}\text { Rotter, 1966; Brockhaus, 1982; Gartner, 1985; Begley y Boyd, 1987; Shaver y Scott, 1991; Chatterjee y Das, 2015; } \\
\text { Espíritu-Olmos y Sastre-Castillo, 2015; Hsiao, Lee y Chen, 2016; Knopf, Stone, y Winston, } 2017 .\end{array}$ \\
\hline Motivation & $\begin{array}{l}\text { McClelland, 1961; Begley y Boyd, 1987; Cunningham y Lischeron, 1991; Herron y Robinson, 1993; Shane y } \\
\text { Venkataraman, 2000; Shane, Locke y Collins, 2003; Segal, Borgia y Schoenfeld, 2005; Ismail, Husin, Rahim, Kamal y } \\
\text { Mat, } 2016 .\end{array}$ \\
\hline Persistence & $\begin{array}{l}\text { Mitton, 1989; Schindehutte, Morris y Allen, 2006; Cardon, Wincent, Singh y Drnovsek, 2009; Gielnik, Spitzmuller, } \\
\text { Schmitt, Klemann y Frese, 2015; Adomako, Danso, Uddin y Damoah, 2016. }\end{array}$ \\
\hline Persuasion & Schumpeter, 1982; Shane y Venkataraman, 2000; Shane, 2003; Álvarez y Busenitz, 2001. \\
\hline Possession of information & Schumpeter, 1982; Shane y Venkataraman, 2000; Shane, 2003; Álvarez y Busenitz, 2001. \\
\hline Tendency to take risks & $\begin{array}{l}\text { Mill, 1872; Schumpeter, 1982; McClelland, 1961; Brockhaus, 1980; Shane y Venkataraman, 2000; Lüthje y Franke, } \\
\text { 2003; Rauch y Frese, 2007; Kreiser, Marino, Kuratko y Weaver, 2013; Chatterjee y Das, 2015; Espíritu-Olmos y } \\
\text { Sastre-Castillo, 2015. }\end{array}$ \\
\hline $\begin{array}{l}\text { Tolerance for failure and un- } \\
\text { certainty }\end{array}$ & $\begin{array}{l}\text { Budner, 1962; Begley y Boyd, 1987; Mitton, 1989; McGrath, 1999; Sarasvathy, 2001; Shepherd, 2003; Minniti 2005; } \\
\text { Politis, 2005, 2008; Politis y Gabrielsson, 2009; Cope, 2011; Cacciotti y Hayton, 2015; Chatterjee y Das, } 2015 .\end{array}$ \\
\hline $\begin{array}{l}\text { Decision making and prob- } \\
\text { lem solving }\end{array}$ & $\begin{array}{l}\text { Covin y Slevin, 1991; Gartner, Bird y Starr, 1992; Sarasvathy, 2001; Dane y Pratt, 2007; Miao y Liu, 2010; Shepherd, } \\
\text { 2011; Holland y Garrett, 2015; Maine, Soh y Dos Santos, 2015; Martina, 2018. }\end{array}$ \\
\hline
\end{tabular}

After identifying and analyzing the attributes that define and characterize the entrepreneur, these were integrated and analyzed from the competence-based approach, including its three dimensions: knowledge (knowing how to know), skills (knowing how to do), and attitudes and values (knowing how to be and know how to live together). 
For carry this analysis out, each attribute was located within each of the dimensions that it is composed of (knowledge, skills, and attitudes and values).

In this research, competence is analyzed from a systemic point of view since the attributes considered key in the specialized literature are integrated into their dimensions and are globally evaluated. It assumes that the attributes of people are essential for business creation, growth, and strengthening. The attributes analyzed in the Kempem Model are presented in Table 2 .

Table 2. Attributes of entrepreneurial competence relative to the Kempem model. Source: Prepared by the authors on the basis of $[4,13-31,38,46,47,49,50,54,56-132]$.

\begin{tabular}{lll}
\hline \multicolumn{1}{c}{ Knowledge } & \multicolumn{1}{c}{ Skills } & \multicolumn{1}{c}{ Attitude and Values } \\
\hline - Autonomous learning & $\bullet$ Exploit opportunities & • Self-efficacy \\
$\bullet$ Previous experience & $\bullet$ Development of contact networks & $\bullet$ Competitiveness \\
$\bullet$ Critical thinking & $\bullet$ Creativity and innovation & $\bullet$ Confidence \\
$\bullet$ Possession of information & $\bullet$ Leadership & $\bullet$ Nonconformity and individualism \\
& $\bullet$ Persuasion & • Legitimacy \\
& $\bullet$ Decision making and problem solving & • Internal locus of control \\
& & $\bullet$ Motivation \\
& & $\bullet$ Persistence \\
& & $\bullet$ Tendency to take risks \\
& & Tolerance for failure and uncertainty \\
\hline
\end{tabular}

From what was outlined above and in agreement with Villa and Poblete [134], it follows that an inseparable characteristic of competence is that it must be demonstrated in performance and be verifiable in practice through evident behaviors. Competence is demonstrated in the manner the person solves problems, how they relate to and work with others, what interpersonal attitudes they demonstrate, and what values they manifest. This demonstration of being competent requires the integration of its three dimensions, namely knowledge, skills, and attitudes and values. The lack of some of them or the lack of integration can result in a manifestation of incompetence.

Although there are various methods used to identify, classify, and rank entrepreneurs (each with a very particular set of criteria), none of the methods focuses on the comprehensive measurement and analysis of the entrepreneur's attributes (knowledge, skills, attitudes and values) necessary for the objective assessment (individual and group) of entrepreneurial competence through the use of machine learning.

Given that stakeholders interested in projects have a great interest in evaluating the value that entrepreneurs bring to organizations, it is necessary to have adequate evaluation and support tools for classifying and ranking them effectively [135-138]. In this sense, Barclay and Osei-Bryson [139] point out that one of the main problems in evaluating project performance is the use of traditional systems associated with costs, deadlines, and specifications. These criteria have been considered incomplete by many researchers [140]. This gap has been identified as the basis for a high incidence of project failure [141]. However, despite their inconsistencies, these measures continue to dominate the practice [142]. That is why we consider it necessary to provide a model that implies the optimization of measures for the evaluation and analysis not only of the projects but also of the people involved in them.

The Kempem Model is an automated methodology that allows the measure and analysis of 20 attributes of entrepreneurial competence grouped into three dimensions (knowledge, skills, and attitudes and values) and displays the level of maturity of the current and potential performance of people. It has been applied in several samples: university students, internal entrepreneurs, independent entrepreneurs, and even some pilot tests that have been carried out in adolescents $[3,23,143]$. 
The model allows the identification, classification, and ranking of the factors that condition high-level performance in individuals. In addition, it has a multivariate approach, where the statistical analyses carried out together with the use of machine learning tools are aimed at evaluating current performance without bias and for developing predictive analyses of the future performance of the person by continuous improvement of the algorithm. As more data are entered, it becomes more effective and efficient. In this manner, the model is optimized by processing, evaluation, and machine learning through the use of the analyzed data set.

\section{Materials and Methods}

The global objective of machine learning is to use algorithms to discover information in the available data that, when applied, contributes to making decisions about the actions to be taken in the future. In this particular case, there is a database made up of the responses provided by individuals to a series of questions and various dimensionality reduction and classification techniques were used to separate the individuals into three disjoint classes that corresponded to the level of maturity: low, medium, and high.

For the processing and analysis of the data presented in this article, the algorithm was coded in Jupyter Notebook which is an interactive extension of the Python console and the following libraries were used among others: sklearn, scipy, matplotlib, numpy, and pandas. This programming language allows the detection of errors, elimination of biases, and the validation of variables at runtime.

In the study, it was observed that, in each dimension, many of the items were related and that it was possible to perform a dimensionality reduction in order to facilitate the execution time of the algorithm that was developed within the framework of the Kempem Model. In addition, it is important to note that some individuals did not answer all the items and, therefore, their responses were recorded as "NaN" (Not a Number). In this manner, the first activity was focused on data purification and avoiding those individuals who possessed $\mathrm{NaN}$ (missing data), eliminating them from the database that would be used to execute the algorithm.

Many authors indicate that some algorithms in machine learning do not work properly when the data possesses different units of measurement [144]. For this reason, the next activity to execute consisted of standardizing the data, that is, subtracting the arithmetic mean and dividing it by the standard deviation. In this particular case, all the data were in the same unit of measure, which means that it was not necessary to perform the aforementioned scaling. However, standardization was carried out in order to optimize the algorithm as much as possible and, in the future, to permit us to handle data that possess different units of measurement.

For the processing and treatment of the data and the corresponding execution of the algorithm, the following methodology corresponding to the Kempem Method was followed:

1. After filtering the data, we proceeded to perform dimensionality reduction for the three dimensions: knowledge, skills, and attitudes and values using a singular value decomposition and taking the eigenvectors with the highest associated singular values (component).

2. Once the main components were obtained, the contribution of each of the items that make up each dimension in each of the attributes was analyzed.

3. Using the data in a smaller dimension for which the base is provided by principal components, a dendrogram type graph was used using the Ward method with Euclidean distances. This procedure allowed us to observe that the data can be divided into three different classes.

4. With the above information, a linear discriminant analysis was performed to separate and further evidence such division.

5. The scores that made it possible to detect joint possession of the attributes of entrepreneurial competence were generated by logistic regression since it is a model that allows the identification of the relationships between independent variables that can 
be of any type and scale. The result of the adjustment is a score contained between zero and one, which is similar to a probability.

6. The dependent variable was defined with a value of 1 if the subject belonged to the group "high potential entrepreneurs". For the rest of the individuals, the value zero was assigned.

7. All the regression coefficients were significant, which means that all the attributes had an effect on the determination of entrepreneurial competence.

8. The model was evaluated with the test data and the results were shown in a confusion matrix that indicated its level of precision.

9. The normality of the distribution of the scores of the individuals is verified using the created model.

10. Each individual is scored between 0 and 5 per attribute and the individual is also scored between 0 and 10 per dimension.

11. The scores for all main components (attributes) are included.

12. Individuals are identified, ranked from 0 to 100, and classified into three groups (red, yellow, and green), which represents the entrepreneurial maturity metric.

\section{Results}

After the exploratory analysis of the data, no anomalies, atypicalities, or missing data were detected in the collected items. From the attributes that make up the three dimensions of entrepreneurial competence that are used as the main components, we proceeded to identify the groupings in each of the dimensions in order to find the group for which joint ownership could be measured in high values of the attributes that define entrepreneurial competence. Next, the discrimination of the results obtained in each of the dimensions is evaluated.

\subsection{Knowledge}

In Figure 1, it is observed that the contribution of the rest is minimal from the fourth singular value. Therefore, we only considered the first four singular vectors or principal components for the 27 items of the knowledge dimension that corresponded to $55.12 \%$ of variability.

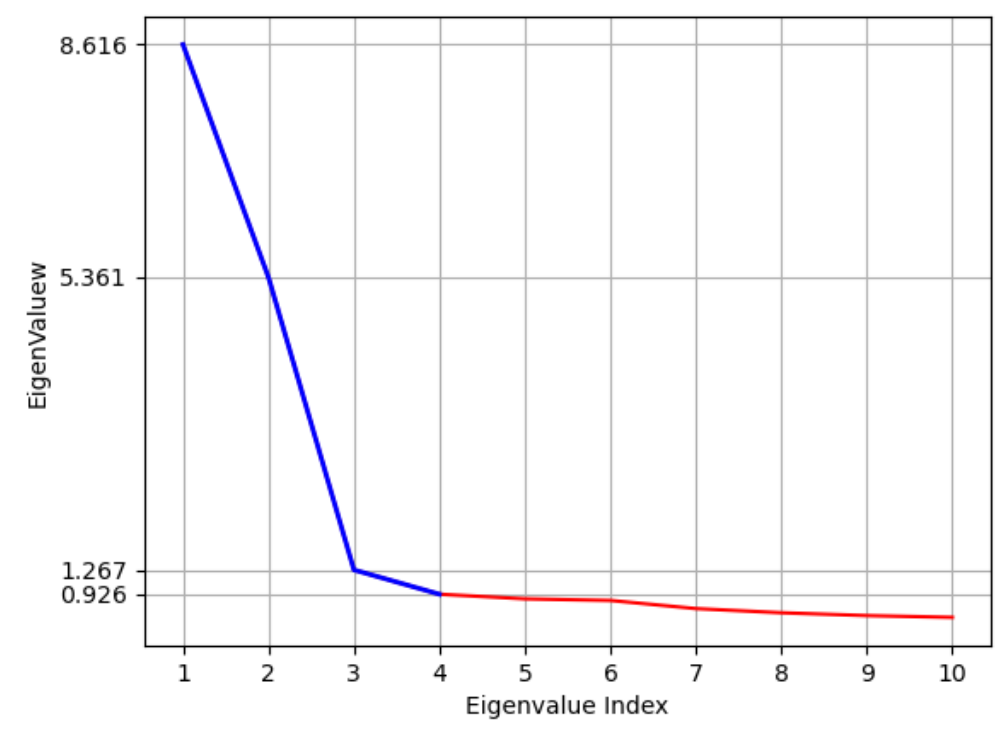

Figure 1. Explained variance for the knowledge dimension.

From the four main components, the contribution of each of the 27 items that make up the knowledge dimension in each of the components was analyzed. When performing this, it was observed that each component corresponds to the following attributes: 
- Autonomous learning: The faculty that takes conceptual and abstract information on where and how to obtain unappreciated resources, both explicit and tacit, and how to use them efficiently;

- Previous experience: Tacit knowledge acquired from the practices associated with the individual's learning, includes work, professional, entrepreneurial, and managerial experiences and those that are acquired by a relationship with a specific industry;

- Critical thinking: The ability to carry out evaluations, judgments, or make decisions associated with the analysis of an opportunity, the creation of a business, and its growth by using simplified mental models aimed at joining information that was previously disjointed;

- Possession of information: This covers all the data, concepts, or theories previously acquired and that individuals use during the process of discovering and taking advantage of opportunities and the formation of new businesses.

We can observe a dendogram in Figure 2 where we can find that the data can be partitioned into three different clusters (Figure 3).

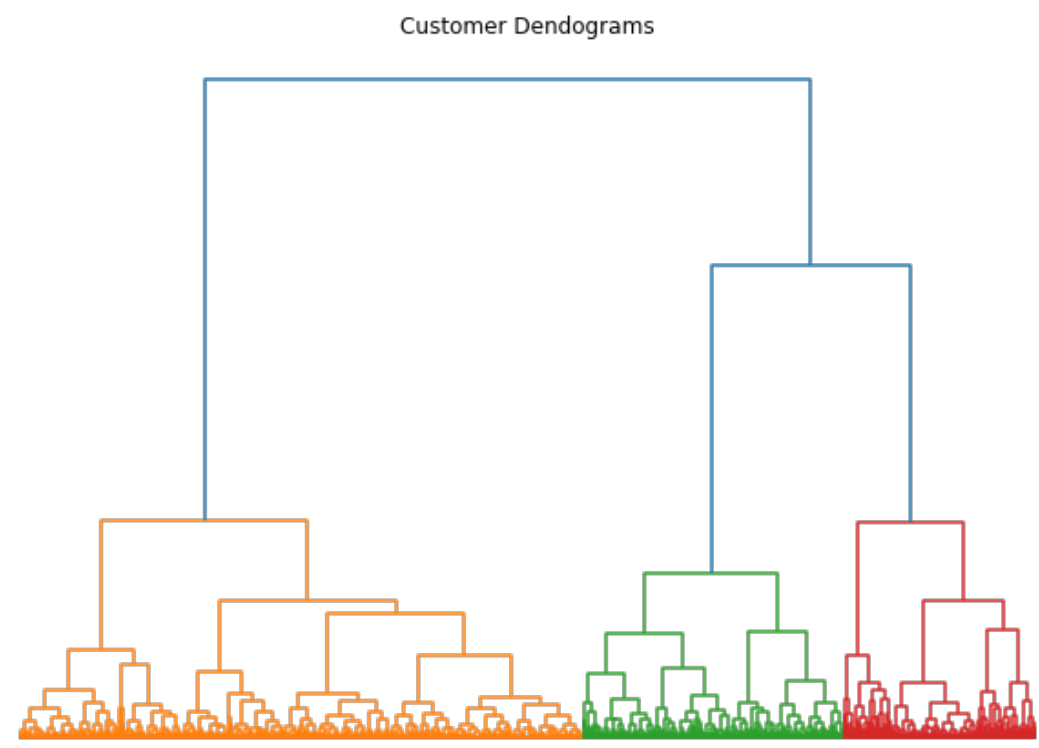

Figure 2. Dendogram for the knowledge dimension.

Using linear discriminant analysis, we observe a two dimensional graph of the clustering.

When we evaluate the predictive model by using logistic regression with the test data, a precision of $98.96 \%$ is yielded and this can be observed in the confusion matrix represented in Table 3.

Table 3. Confusion matrix for the logistic model of the knowledge dimension.

\begin{tabular}{|c|c|c|c|c|}
\hline \multirow{5}{*}{ 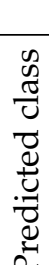 } & \multicolumn{4}{|c|}{ Actual Class } \\
\hline & & Low Maturity & Medium Maturity & High Maturity \\
\hline & Low maturity & 1689 & 5 & 7 \\
\hline & Medium maturity & 3 & 3670 & 18 \\
\hline & High maturity & 11 & 25 & 1221 \\
\hline
\end{tabular}

In Figure 4, it can be observed that the distribution of the score of the individuals using the model created by regression is normal. 


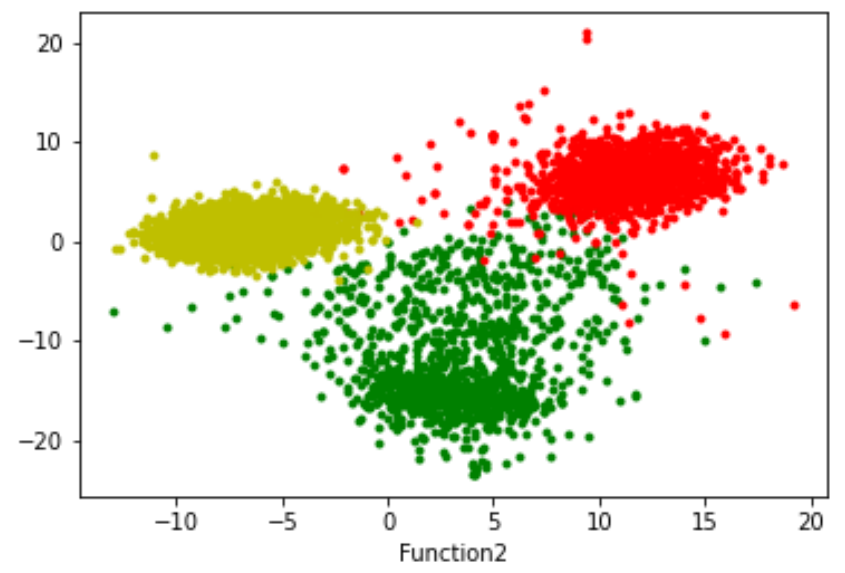

Figure 3. Linear discriminant analysis for the knowledge dimension.

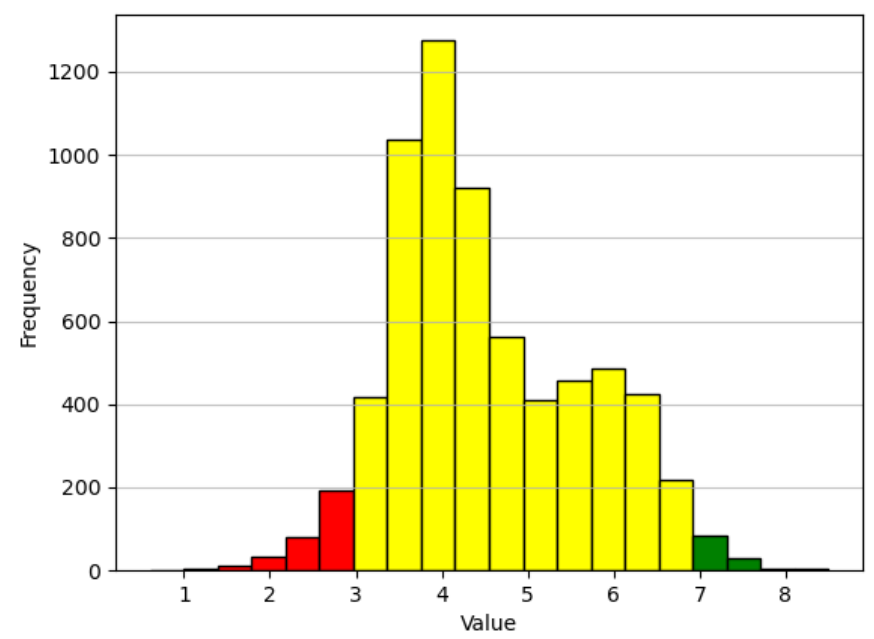

Figure 4. Distribution of scores of individuals using the Kempem Model for the knowledge dimension.

\subsection{Skills}

For the skills dimension (43 items), in this case after performing principal component analysis, the six components were considered and they corresponded to $48 \%$ of the variability (Figure 5).

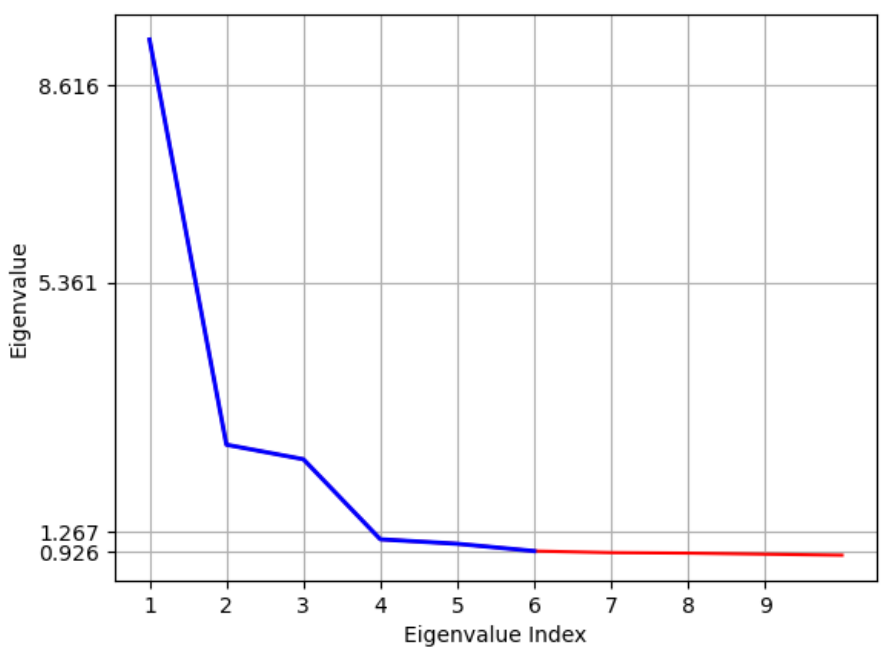

Figure 5. Explained variance for the skills dimension. 
After the corresponding analysis to determine the contribution of each item in each of the main components, it is observed that these components correspond to the following attributes:

- Exploit opportunities: Subjective action oriented to the ability to identify new combinations of available resources and information through constant inquiry into the environment and observation of changes;

- Development of contact networks: This consists of building and transforming relationships of an effective nature into relationships of an instrumental nature in order to acquire trust, be more efficient, promote the exchange of resources, provide ideas, access privileged business opportunities, and to obtain the commitment, help, and skills of the actors involved in order to materialize a project or task and to improve innovation;

- Creativity and innovation: The behavioral pattern of an individual who is interested in creating change and carrying out a dynamic that pushes the market on a model of imbalance that permits developing, acquiring, building, or managing new products, processes, services, materials raw materials, and methods of organization;

- Leadership: The ability to define a vision of what is possible and to attract people to work together on it in order to transform the vision into reality by facilitating individual and collective efforts to achieve a shared goal;

- Persuasion: The process of influencing or convincing people to change their attitude or behavior in order to define a vision of what is possible or what you want to achieve;

- Decision making and problem solving: This involves choosing between possible effects of an action using a set of given means and, in addition, choosing the set of means to achieve a desired effect. This is especially applied in situations where there are no historical trends, levels performance reports, and little or no specific information. Therefore, the future is highly uncertain and the nature or precise characteristics of the objectives are not known with any degree of certainty.

As in the case of knowledge, the data are visualized using a dendrogram with the Ward method and Euclidean distance. Furthermore, it is also observed that the data can be classified into three classes (Figure 6). Three classes are contemplated in the dendrogram, although two of them are close enough not to be differentiated by color.

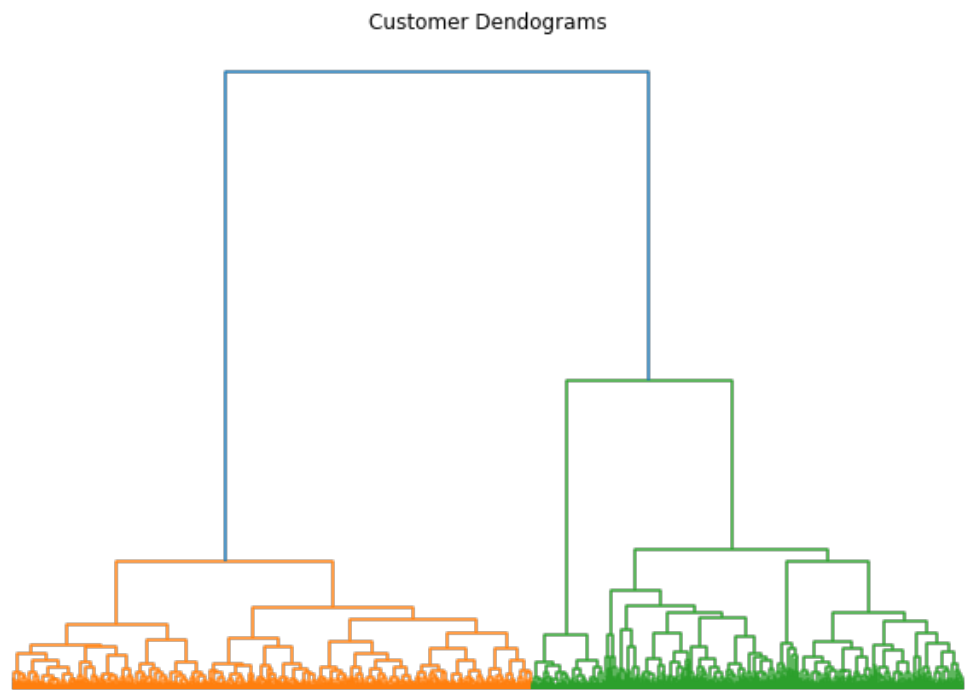

Figure 6. Dendogram for the skills dimension.

Figure 7 corresponds to the linear discriminant analysis. We can observe the separation of the classes. 


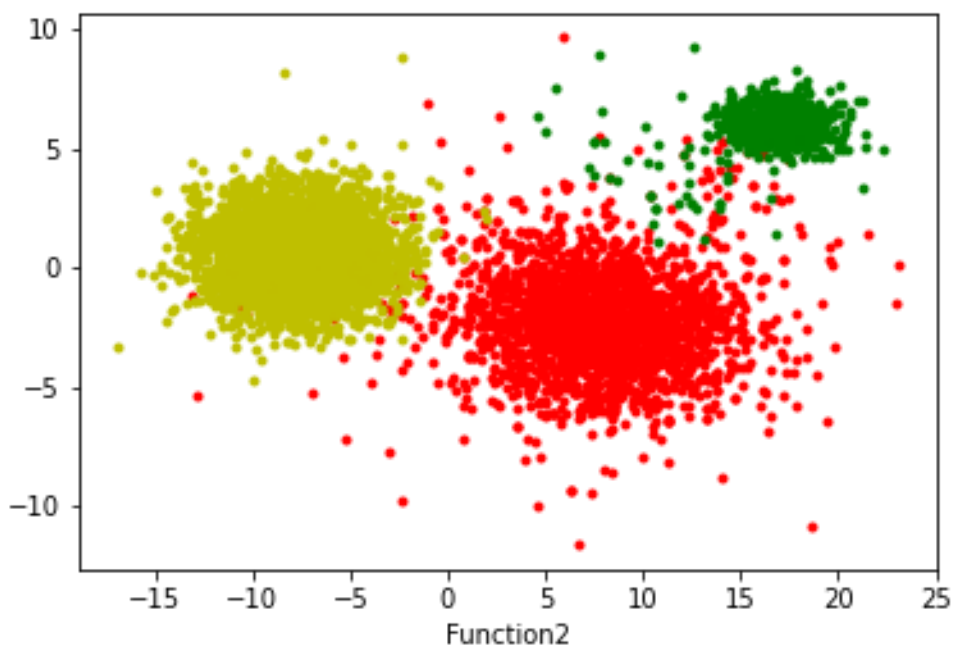

Figure 7. Linear discriminant analysis for the skills dimension.

A certainty of $99.23 \%$ is observed when we evaluate the data within the model. It can be observed in the corresponding confusion matrix shown in Table 4.

Table 4. Confusion matrix for the logistic model of the skills dimension.

\section{Actual Class}

\begin{tabular}{|c|c|c|c|}
\hline & Low Maturity & Medium Maturity & High Maturity \\
\hline Low maturity & 2463 & 29 & 9 \\
\hline Medium maturity & 10 & 3622 & 0 \\
\hline High maturity & 3 & 0 & 513 \\
\hline
\end{tabular}

As in the previous case, the score of the individuals obtained using the Kempem Model for the skills dimension is adjusted to a Gaussian model (Figure 8).

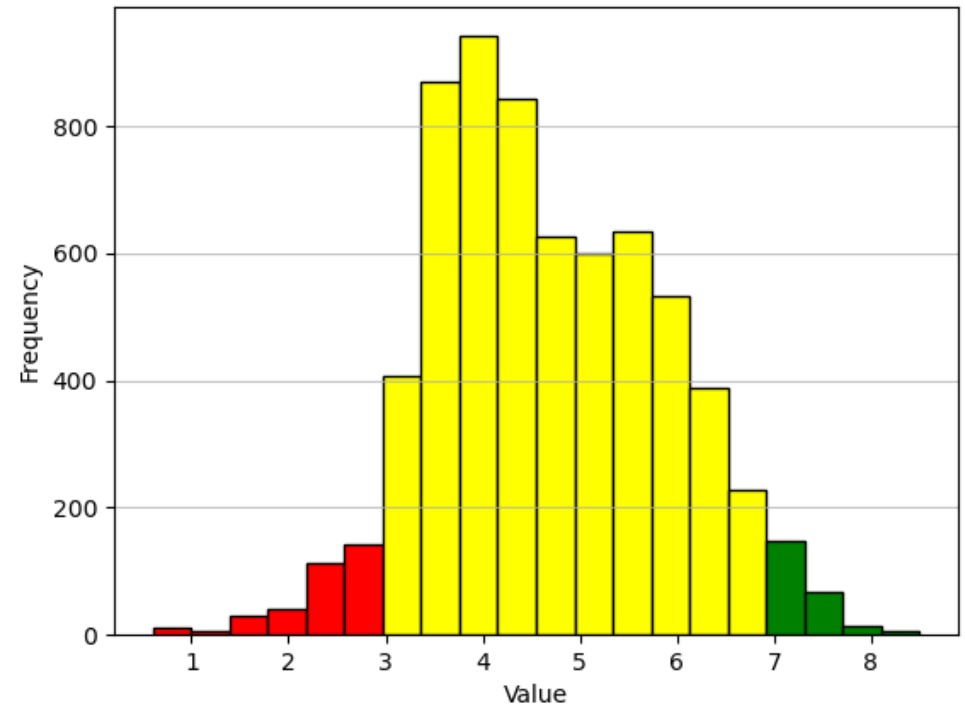

Figure 8. Distribution of scores of individuals using the Kempem Model for the skills dimension.

\subsection{Attitudes and Values}

For the attitudes and values dimension, the remaining 77 items were reduced to only ten main components with a variability of $39.69 \%$ (Figure 9). 


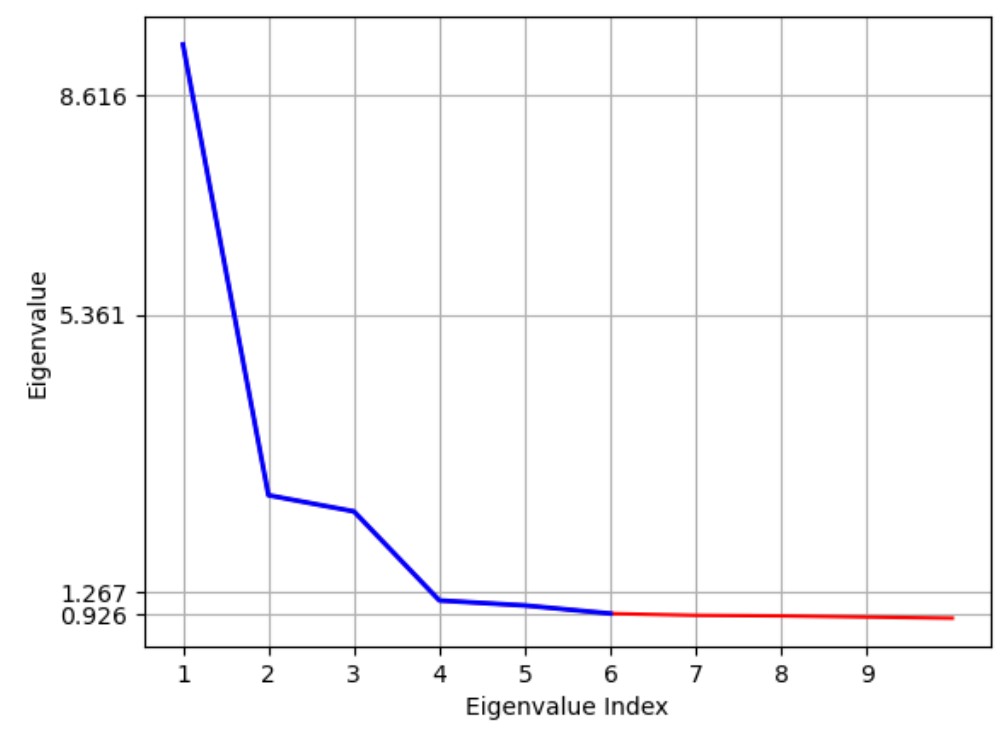

Figure 9. Explained variance for attitudes and values dimension.

These main components correspond to the following attributes:

- Self-efficacy: The belief that an individual has the individual ability to pursue and persist to achieve a goal, even in the face of skepticism from others.

- Competitiveness: The complex action-emotion of an individual who is aggressively involved in a chronic and incessant struggle to achieve more in less time and who, if necessary, will do so against the opposing efforts of other situations, means, or persons.

- Confidence: This arises when individuals are optimistic and confident in their analysis of a situation by using their estimation skills and recognizing the uncertainty that really exists.

- Nonconformity and individualism: The ability to execute a series of initiatives that contribute to improving the environment. This implies thinking in a personal capacity outside the established margins for the generation of new products, processes, services, markets, projects, or companies.

- Legitimacy: The deliberate manipulation of the individual and her project, which allows external actors to perceive a sense of relative permanence of the project that is being initiated.

- Internal locus of control: The perception that rewards are a consequence of an individual's behavior; that is, the ability perceived by subjects to directly influence events in their lives.

- Motivation: The incentive that leads people to carry out specific actions and that must necessarily be intrinsic because they are motivated to achieve their goals, they enjoy the process of performing it, they obtain personal satisfaction, or because the activity is significant in itself for them.

- Persistence: The continuity of actions that involve intense effort during long and difficult hours regardless of the obstacles that arise in order to meet the proposed objectives. The level of commitment helps individuals overcome fatigue and failure to achieve a goal.

- $\quad$ Tendency to take risks: The perceived probability of receiving rewards associated with the success of a specific situation and for which the alternative provides fewer rewards as well as less severe consequences.

- $\quad$ Tolerance to failure and uncertainty: The ability to accept that failure is a learning technique that provides the opportunity to diagnose why an error has occurred; failures provide information to discover uncertainties that were previously unpredictable. 
As in the case of knowledge, the data are visualized using a dendrogram with the Ward method and Euclidean distances. Furthermore, observing that the data can be classified into three classes (Figure 10).

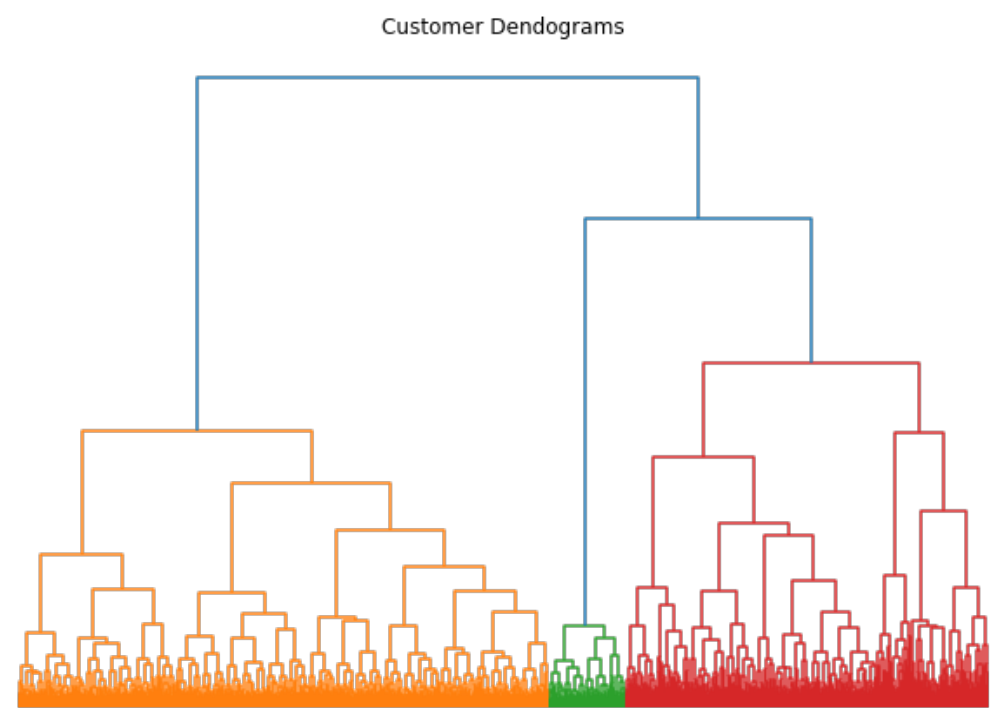

Figure 10. Dendogram for the attitudes and values dimension.

We see the clustering in three classes with a projection in two dimensions using the linear discriminant analysis. See Figure 11.

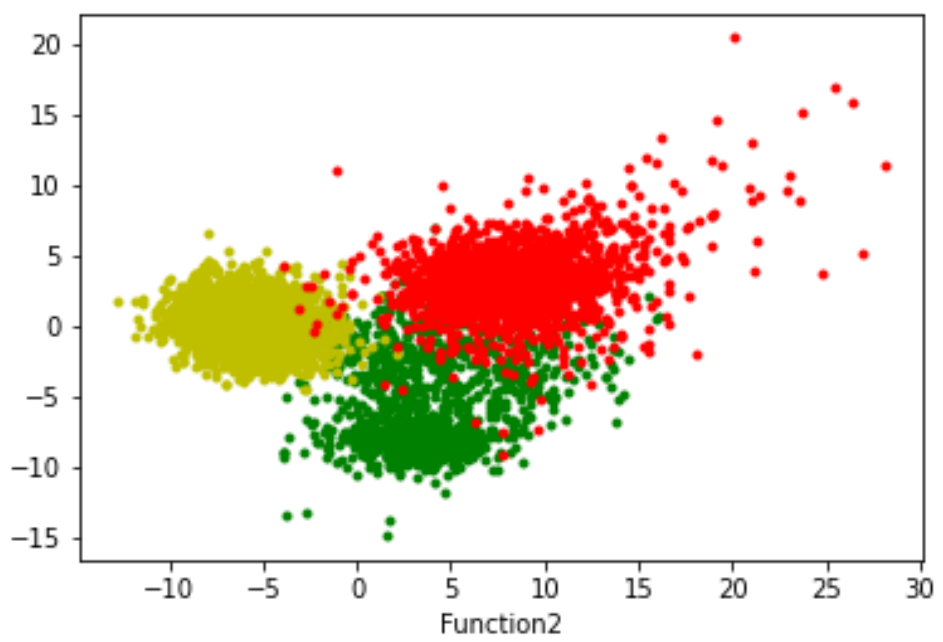

Figure 11. Linear discriminant analysis for the attitudes and values dimension.

The model is created using logistic regression and has an accuracy of $98.73 \%$ as can be observed in the confusion matrix provided in Table 5.

Table 5. Confusion matrix for the logistic model of the skills, attitudes, and values

\begin{tabular}{|c|c|c|c|c|}
\hline \multirow{5}{*}{ 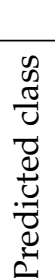 } & \multicolumn{4}{|c|}{ Actual Class } \\
\hline & & Low Maturity & Medium Maturity & High Maturity \\
\hline & Low maturity & 2436 & 36 & 7 \\
\hline & Medium maturity & 32 & 3611 & 0 \\
\hline & High maturity & 8 & 1 & 518 \\
\hline
\end{tabular}


As in the previous case, the scores of the individuals obtained using the Kempem Model for the attitudes and values dimension also fits a Gaussian model (see Figure 12).

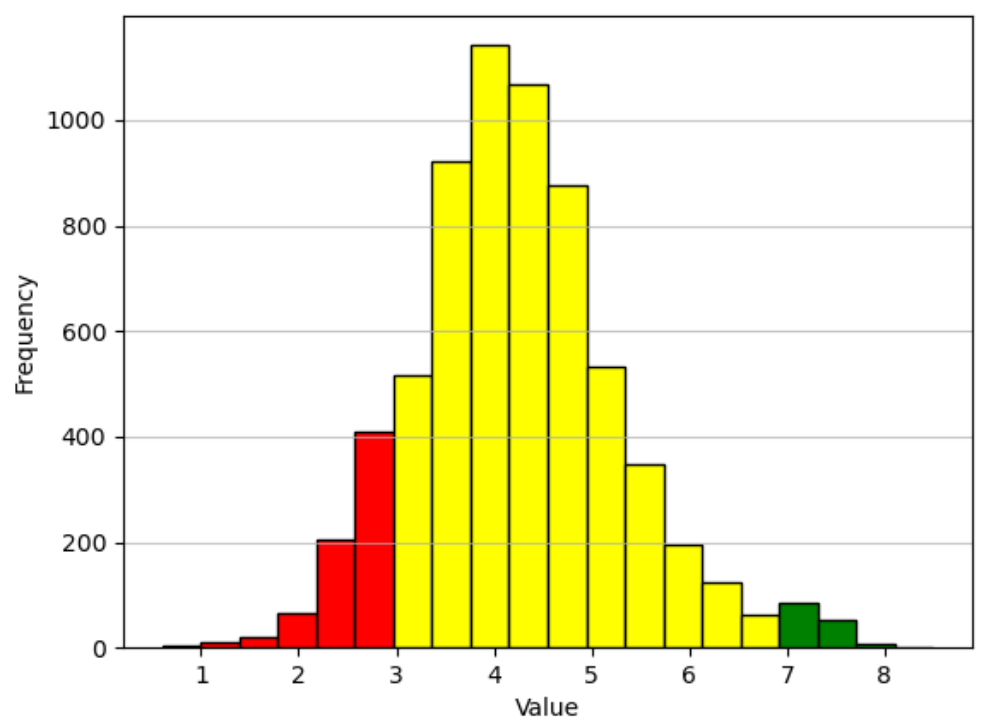

Figure 12. Distribution of scores of individuals using the Kempem Model for the attitudes and values dimension.

In Figure 13, the score obtained by one of the individuals analyzed in each of the main components (attributes of entrepreneurial competence) is observed in comparison with the results obtained by the total group (6649 individuals).

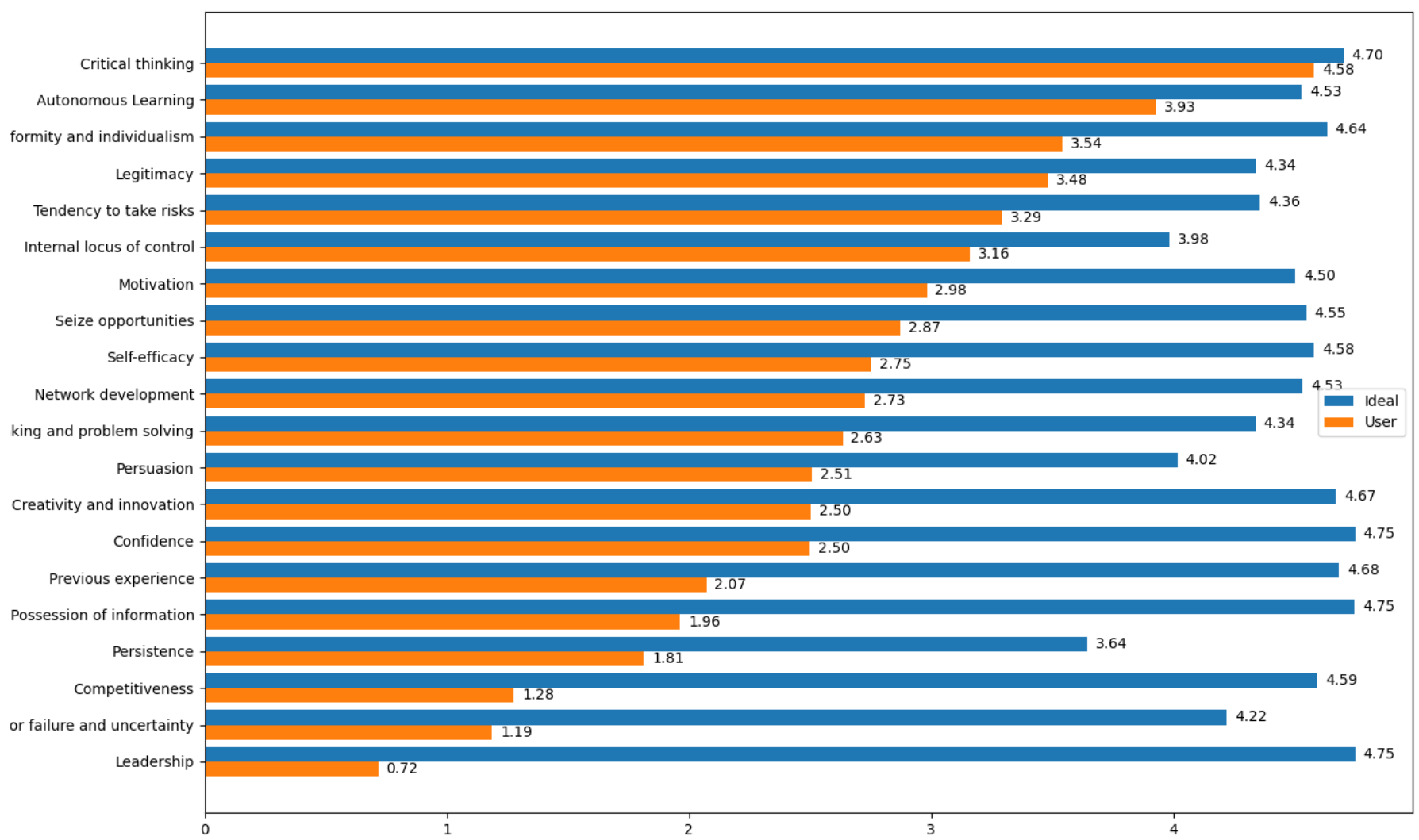

Figure 13. Score obtained by an individual in each of the main components. 
The average of the individuals compared to the average of the ideal value in each dimension is presented in Figure 14.

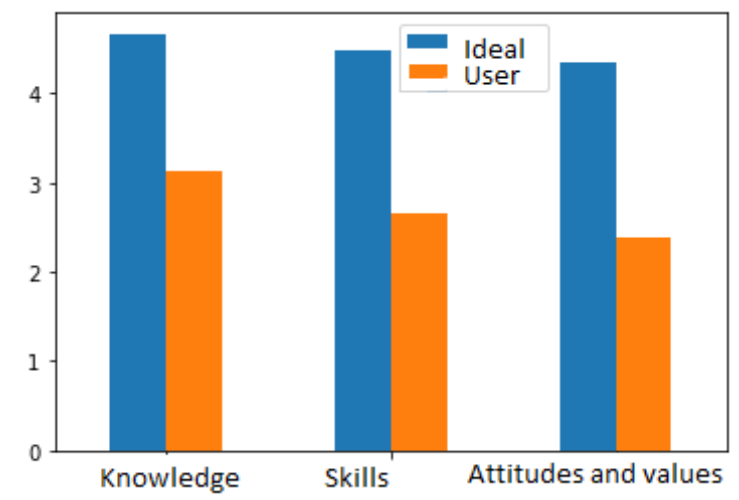

Figure 14. Global ideal and average of the score in each dimension.

Finally, each individual was assigned a global score that permits them to be classified and ranked with low, medium, or high maturity. The graph of the distribution of global individuals can be observed in Figure 15.

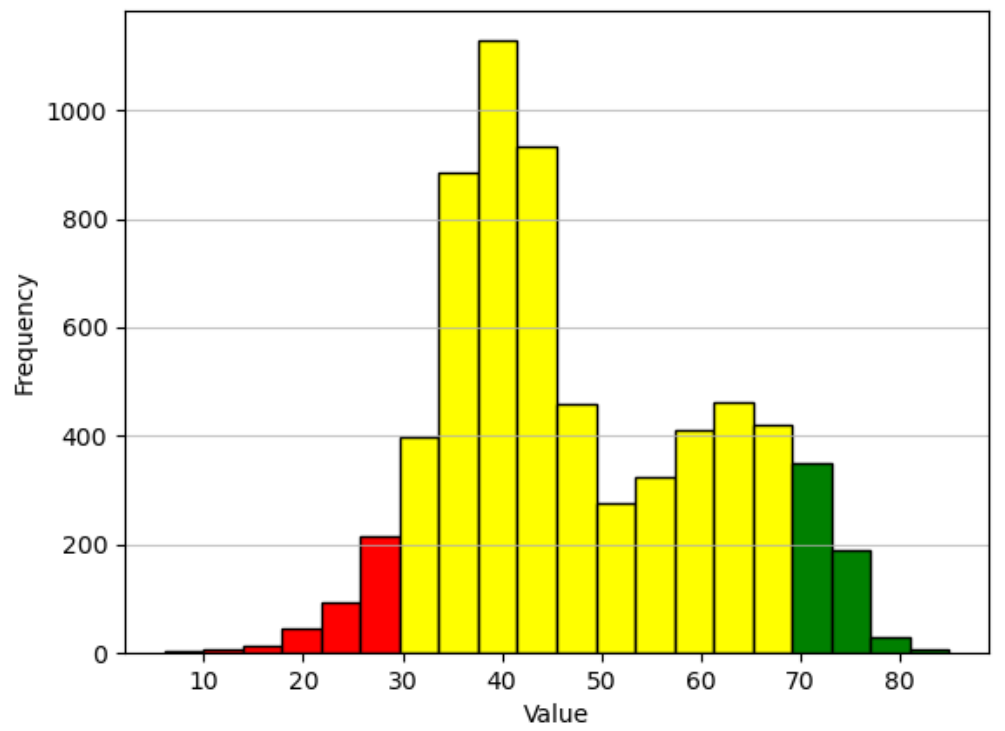

Figure 15. Distribution of the global score.

\section{Discussion and Conclusions}

Knowing entrepreneurs and their attributes is of utmost importance for the development of current societies, but it is a complex problem given its multidimensional and transdisciplinary nature.

The present work is novel for the application of predictive analysis from the machine learning approach (unsupervised learning) to determine which individuals are entrepreneurs.

The methodology corresponding to the Kempem Method has been followed and, with it, three groups were obtained. The first one, with a weight of $5.47 \%$, has very low valuations in the measured attributes. The second is of larger size, with $85.68 \%$ that presented gaps in many of them. Finally, with a proportion of $8.85 \%$, a group with high scores was obtained for entrepreneurial competence jointly in its dimensions and attributes. This is the grouping that, for the purposes of this article, is called "high potential entrepreneurs" and for whom scoring systems were generated that allowed their identification, classification, and proper ranking in a metric of "entrepreneurial maturity" ranging from 0 to 100. 
This study not only contributes to the construction of the concept of entrepreneurial competence from the adoption of the 20 attributes associated with entrepreneurial behavior and their characterization using machine learning techniques but also contributes to the results obtained from the application of emerging tools in data science in the research on entrepreneurs. This is because the results permitted the development of a predictive model with a scoring system that determines the degree of possession of entrepreneurial competence in individuals, as well as the gaps for each attribute and dimension.

The findings of this investigation are consistent with other investigations that indicate the positive and significant influence of knowledge on entrepreneurial behavior [84,145-149]. These studies indicate that the individual who wishes to create a company must begin to carry out some activities such as the following: preparing business plans, acquiring resources, organizing the start-up of the business, requesting licenses or patents, and developing models or prototypes among other activities for which he needs to develop autonomous learning and critical thinking. In addition, the entrepreneur must possess information and have previous experience; these are factors that are part of the knowledge dimension proposed in this paper. Thus, we can point out that the knowledge acquired through previous experience and the possession of information becomes useful when creating a company, since they can increase the methods in which entrepreneurs identify new opportunities and how they can take advantage of them efficiently. Regarding autonomous learning and critical thinking, the entrepreneur must be aware of the relevance of developing the necessary knowledge that allows them to be efficient in the creation and management of new businesses. It is necessary for the entrepreneur to be able to take advantage of any abstract information that they acquire in order to know where and how you obtain the resources for your company and, also, how to use and take advantage of them.

Additionally, it was found that the skills measured in this study also have a positive and significant influence on entrepreneurial behavior. This relationship has already been established in previous studies [13,149-152], which indicate that the individual depends on skills, such as taking advantage of opportunities, since they must perceive that the decision for starting a business stems from a credible opportunity. It was also observed that other skills are necessary, such as creativity and innovation, in order to start designing the possible new business model that he wants to carry out based on the identified opportunities. Likewise, the development of social capital or contact networks is essential, since these networks are the greatest source of information for entrepreneurs and, as they interact, they can expand their own networks and find valuable resources for the development of their ventures. On the other hand, they can check if their business ideas have the potential to be implemented and establish links with people who can contribute to the realization of the initial activities for business creation involved in the nascent entrepreneurship through these networks. The fact that they are inclined to action induces them to look for contacts and connections to obtain and fulfill certain conditions that represent advantages for their own entrepreneurial goals. In short, it is necessary to have skills that allow the individual to carry out a series of activities aimed at achieving their goal.

Regarding the attitudes and values dimension, the findings of this research are consistent with the results obtained in previous research $[95,151,152]$ which highlight that persistence is the product of an individual's ability to overcome the skepticism of others and that leads him to commit to the achievement of specific objectives as a result of his intrinsic motivation. Likewise, the decision to take advantage of an opportunity is influenced by different individual perceptions of optimism [46], which contributes to providing the entrepreneur a more positive view of the skepticism of others. Attributes such as self-efficacy, competitiveness, tolerance for failure, and motivation are considered the elementary factors for the creation of a company. The tendency to take risks can serve as a motivational agent to start a new business. Tolerance for uncertainty is essential as new entrepreneurs will begin to encounter changing situations and must be able to adapt and be flexible to the circumstances that arise. Entrepreneurs can view uncertainty as an exciting stimulus rather than a threat when carrying out their initiatives. However, high tolerance for ambiguity 
does not ensure the successful completion of an undertaking and so it is also important that they have tolerance for failure in order to take advantage of failures to modify future behaviors. Tolerance and failure contribute to reducing uncertainty, increasing variety, and expanding the search for new opportunities [74].

The identification, classification, and hierarchy of entrepreneurs through machine learning allows the following:

- Possessing a methodology focused on evaluating people;

- Evaluate accurately and objectively the entrepreneurs who will carry out the projects in order to set criteria and expectations about them;

- Identify high-potential entrepreneurs with a precision greater than 98;

- Determine gaps to design or adjust training programs;

- Efficiently allocate resources for entrepreneurship;

- Identify entrepreneurial attributes in order to enhance or develop them;

- Gather useful information for making strategic decisions;

- Design personalized models of entrepreneurial competence;

- Minimize the risk in capital investment;

- Increase positive impact by appropriately allocating support programs and capital for investment in entrepreneurship.

All of this is aimed at reducing the mortality rate of enterprises (dropouts) and increasing their permanence beyond 42 months.

From an organizational point of view (intrapreneurship), the model allows for the following:

- Collection of useful information for the recruitment of new talents and preparation of career plans, training, evaluation, promotion, and compensation systems;

- Facilitate the adjustment between the job profile and the required attributes based on the processes of selection, location, and training of personnel;

- Evaluate workers accurately and objectively to set criteria and expectations about them;

- Promote the development of human talent by using specific training processes;

- Design personalized models of entrepreneurial competence according to organizational objectives in order to adjust the processes of evaluation and management of worker performance;

- Identify organizational competencies and their strategic alignment;

- Provide feedback to workers about their performance;

- Provide development opportunities and create conditions for the active participation of all members of the organization considering the organizational objectives;

- Promote the individual development of workers;

- Promote workers to carry out positions in a higher field due to the identification of their potential;

- Adjust workers to each position based on the processes of selection, location, and training of personnel;

- Identify workers who hold positions for which they are not prepared due to lack of appropriate training.

Sustainability would be provided because the model promotes the rational, conscious, and responsible use of the available economic resources which allows, through the use of the minimum resources, the benefits to be maximized. Since we are identifying entrepreneurial competence, which include the attributes and entrepreneurial potential in people, it is possible to implement a set of efficient, economically profitable, and ethically balanced practices. The objective of the implementation is to achieve, by using a conscious model of economic development, a higher and better level of social welfare that provides everyone the possibility of accessing a good standard of living and having the same opportunities.

As limitations of the study, we can point out that although the sample used made up of 6649 individuals and is a very remarkable and a positive aspect of the research, we consider 
that it should be extended to other contexts in addition to Latin America. Therefore, an immediate future line of research is to validate the model in other different geopolitical areas. It is also proposed that future investigations should advance other predictive techniques of machine learning, such as the use of neural networks and decision trees in order to optimize the algorithm and to render more efficient identification, classification, and hierarchy of an entrepreneur' high potential.

Author Contributions: Conceptualization: C.R.-K.; methodology: C.R.-K.; software: L.V. and C.R.-K.; validation: C.R.-K. and L.V.; investigation: C.R.-K., L.V., and M.A.S.-C.; data curation: L.V.; writingoriginal draft preparation: C.R.-K. and L.V.; writing-review and editing: M.A.S.-C.; funding acquisition: M.A.S.-C. All authors have read and agreed to the published version of the manuscript.

Funding: The authors express gratitude to the INBOTS project H2020 (grant agreement 780073), the Ministry of Economy and Competitiveness of Spain (Project ECO2014-54301-P), and ISDI for its financial support.

Institutional Review Board Statement: Not applicable.

Conflicts of Interest: The authors declare no conflict of interest.

\section{References}

1. Cantillon, R. Essai Sur la Nature du Commerce en General, Reimpreso por la Universidad de Harvard (1892); Ellis: Boston, MA, USA, 1755; pp. 40-42.

2. Say, J.B. Traité d'économie politique. 2 vols. In Deterville Paris; A.M. Kelly Publishers: New York, NY, USA, 1803 .

3. Polli, I.R.R.; Polli, V.; Vieira, J.H. El Perfil Intraemprendedor Como Factor de Contribución a la Gestión de Personas en las Organizaciones. In The Oxford Handbook of Innovation; Universidad de Valencia: Valencia, Spai , 2004; Chapter 31, pp. $495-506$.

4. Alvarez, S.A.; Busenitz, L.W. The entrepreneurship of resource-based theory. J. Manag. 2001, 27, 755-775. [CrossRef]

5. Herron, L. The Effects of Characteristics of the Entrepreneur on New Venture Performance; University of South Carolina Press: Columbia, SC, USA, 1991.

6. Sandberg, W.R. New Venture Performance: The Role of Strategy and Industry Structure; Lexington Books: Blue Ridge Summit, PA, USA, 1986

7. Cooper, A.C.; Willard, G.E.; Woo, C.Y. Strategies of high performing new and small firms: A reexamination of the niche concept. J. Bus. Ventur. 1986, 1, 247-260. [CrossRef]

8. Shapero, A. The entrepreneurial event. In The Environment for Entrepreneurship; Kent, C.A., Ed.; Lexington Books: Lexington, MA, USA, 1984

9. Aldrich, H.E. Entrepreneurship through social networks. In The Art and Science of Entrepreneurship; Ballinger Press: Cambridge, MA, USA, 198 ; pp. 3-23.

10. Acs, Z.J.; Audretsch, D.B. Innovation, market structure, and firm size. In The Review of Economics and Statistics; MIT Press: Cambridge, MA, USA, 1987; pp. 567-574.

11. Cooper, A.C.; Woo, C.Y.; Dunkelberg, W.C. Entrepreneurs' perceived chances for success. J. Bus. Ventur. 1988, 3, 97-108. [CrossRef]

12. Mitchell, R.K.; Smith, J.B.; Morse, E.A.; Seawright, K.W.; Peredo, A.M.; McKenzie, B. Are entrepreneurial cognitions universal? Assessing entrepreneurial cognitions across cultures. Entrep. Theory Pract. 2002, 26, 9-32. [CrossRef]

13. Gartner, W.B. A conceptual framework for describing the phenomenon of new venture creation. Acad. Manag. Rev. 1985, 10, 696-706. [CrossRef]

14. Gartner, W.B. "Who is an entrepreneur?" is the wrong question. Am. J. Small Bus. 1988, 12, 11-32. [CrossRef]

15. Covin, J.G.; Slevin, D.P. A conceptual model of entrepreneurship as firm behavior. Entrep. Theory Pract. 1991, 16, 7-26. [CrossRef]

16. Covin, J.G.; Slevin, D.P. Leadership, Entrepreneurial. In Wiley Encyclopedia of Management; Elsevier: Amsterdam, The Netherlands, 2015; pp. 1-4.

17. Adomako, S.; Danso, A.; Uddin, M.; Damoah, J.O. Entrepreneurs' optimism, cognitive style and persistence. Int. J. Entrep. Behav. Res. 2016, 22, 84-108. [CrossRef]

18. Cunningham, J.B.; Lischeron, J. Defining entrepreneurship. J. Small Bus. Manag. 1991, 29, 45-61.

19. Stanley Budner, N. Intolerance of ambiguity as a personality variable 1. J. Personal. 1962, 30, 29-50. [CrossRef]

20. Fiedler, F.E. Leadership effectiveness. Am. Behav. Sci. 1981, 24, 619-632. [CrossRef]

21. Bandura, A. Self-efficacy: Toward a unifying theory of behavioral change. Psychol. Rev. 1977, 84, 191. [CrossRef] [PubMed]

22. Bandura, A. Self-efficacy mechanism in human agency. Am. Psychol. 1982, 37, 122. [CrossRef]

23. Brockhaus Sr, R.H. Risk taking propensity of entrepreneurs. Acad. Manag. J. 1980, 23, 509-520.

24. Espiritu-Olmos, R.; Sastre-Castillo, M.A. Personality traits versus work values: Comparing psychological theories on entrepreneurial intention. J. Bus. Res. 2015, 68, 1595-1598. [CrossRef]

25. Dane, E.; Pratt, M.G. Exploring intuition and its role in managerial decision making. Acad. Manag. Rev. 2007, 32, 33-54. [CrossRef] 
26. Rivera-Kempis, C. Competencia emprendedora y comportamiento emprendedor: Análisis en el contexto venezolano. Ph.D. Thesis, Universidad Complutense de Madrid, Madrid, Spai , 2014.

27. Rivera-Kempis, C.; Montoro-Sánchez, M.Á. El comportamiento emprendedor desde el enfoque basado en las competencias: Una propuesta teórica/Entrepreneurial behavior from a competence based view: A theoretical perspective. In Anales de la Universidad Metropolitana; Universidad Metropolitana: Caracas, Venezuela, 2015; Volume 15, p. 59.

28. Rivera-Kempis, C.; Prat, J. Evaluacion de la competencia emprendedora: Propuesta de escala de medicion. In Conferencia Iberica de Empreendedorismo; Universidad de Salamanca: Salamanca, Spain, 2018; Volume 8.

29. Weinert, F.E. Concept of competence: A conceptual clarification. In Defining and Selecting Key Competencies; Hogrefe \& Huber Publishers: Seattle, WA, USA, 2001; pp. 45-65

30. Tobón, S. Formación Basada en Competencias: Pensamiento Complejo, Diseño Curricular y Didáctica; Ecoe Ediciones: Bogota, Colombia, 2005.

31. Rivera-Kempis, C.; Prat, J. Validacion de una escala para medir la competencia emprendedora. In Emprendimiento e Innovación: Oportunidades Para Todos; Universidad de Cordoba: Cordoba, Spain; Librería Dykinson: Madrid, Spain, 2019 ; pp. 85-91.

32. Rychen, D.S.; Salganik, L.H. Key Competencies for a Successful Life and Well-Functioning Society; Hogrefe Publishing: Gottingen, Germany, 2003.

33. González, J.; Wagenaar, R. Tuning Educational Structures in Europe: Informe Final Fase uno; Universidad de Deusto: Bilbao, Spain; Universidad de Groningen: Groningen, The Netherlands; Estudios Sobre Educación: Bilbao, Portugal, 2003 ; p. 239.

34. Rychen, D.S.; Salganik, L.H. Defining and Selecting Key Competencies; Hogrefe \& Huber Publishers: Gottingen, Germany, 2001.

35. Zabalza, M.; Beraza, M. Competencias Docentes del Profesorado Universitario: Calidad y Desarrollo Profesional; Narcea Ediciones: Madrid, Spain, 2003.

36. Martínez-Clares, P.; Martínez-Juárez, M.; Muñoz-Cantero, J.M. Formación basada en competencias en educación sanitaria: Aproximaciones a enfoques y modelos de competencia. RELIEVE Rev. Electrónica De Investig. Y Evaluación Educ. 2008, 14, 1-23. [CrossRef]

37. Puig, J.; Hartz, B. Concepto de competencia y modelos de competencias de empleabilidad. In Primer Encuentro Internacional de Educación Superior: Formación por Competencias; Universidad de Antioquia: Medellìn, Colombia, 2005.

38. McClelland, D.C. Testing for competence rather than for "intelligence". Am. Psychol. 1973, 28, 1. [CrossRef] [PubMed]

39. Larraín, A.M.; González, L.E. Formación universitaria por competencias. Semin. Int. CINDA. Currículo Univ. Basado En Competencias 2005, 4 , 3-23.

40. Spencer, L.; Spencer, S. Competence at Work; John Wiley \& Sons: New York, NY, USA, 1993.

41. Levy-Leboyer, C.; Prieto, J.M. Gestión de las Competencias: Cómo Analizarlas, cómo Evaluarlas, cómo Desarrollarlas; Gestión Barcelona 2000: Barcelona, Spain, 2001.

42. García, J.; López, N. ¿ Qué son las Competencias en Educación; Gafra Editores: Mexico City, Mexic , 2012.

43. Delors, J.; Amagi, I.; Carneiro, R.; Chung, F.; Geremek, B.; Gorham, W.; Kornhauser, A.; Manley, M.; Padrón Quero, M.; Savané, K.S.; et al. La educación encierra un tesoro: Informe para la UNESCO de la Comisión Internacional sobre la Educación para el Siglo Veintiuno; Santillana-Unesco: Madrid, Spain, 1997.

44. Botello, C.M.S.; Vega, M.C. Competencias y educación superior. Un estudio empírico. Horizontes Educ. 2007, 12, $23-35$.

45. Cuervo, A. Individual and environmental determinants of entrepreneurship. Int. Entrep. Manag. J. 2005, 1, 293-311. [CrossRef]

46. Shane, S.; Venkataraman, S. The promise of entrepreneurship as a field of research. Acad. Manag. Rev. 2000, 25, 217-226. [CrossRef]

47. Herron, L.; Robinson, R.B., Jr. A structural model of the effects of entrepreneurial characteristics on venture performance. J. Bus. Ventur. 1993, 8, 281-294. [CrossRef]

48. Herron, L.; Sapienza, H.J. The entrepreneur and the initiation of new venture launch activities. Entrep. Theory Pract. 1992, 17, 49-55. [CrossRef]

49. Dyer, J.H.; Gregersen, H.B.; Christensen, C. Entrepreneur behaviors, opportunity recognition, and the origins of innovative ventures. Strateg. Entrep. J. 2008, 2, 317-338. [CrossRef]

50. Shane, S.; Locke, E.A.; Collins, C.J. Entrepreneurial motivation. Hum. Resour. Manag. Rev. 2003, 13, 257-279. [CrossRef]

51. Baron, R.A. The cognitive perspective: A valuable tool for answering entrepreneurship's basic "why" questions. J. Bus. Ventur. 2004, 19, 221-239. [CrossRef]

52. Van Praag, C.M.; Versloot, P.H. What is the value of entrepreneurship? A review of recent research. Small Bus. Econ. 2007, 29, 351-382. [CrossRef]

53. Cardon, M.S.; Wincent, J.; Singh, J.; Drnovsek, M. The nature and experience of entrepreneurial passion. Acad. Manag. Rev. 2009, 34, 511-532. [CrossRef]

54. Carsrud, A.; Brännback, M. Entrepreneurial motivations: What do we still need to know? J. Small Bus. Manag. 2011, 49, 9-26. [CrossRef]

55. Sastre-Castillo, M.A.; Peris-Ortiz, M.; Danvila-Del Valle, I. What is different about the profile of the social entrepreneur? Nonprofit Manag. Leadersh. 2015, 25, 349-369. [CrossRef]

56. Mill, J.S. Principles of Political Economy with Some of Their Applications to Social Philosophy; Longmans, Green, Reader, and Dyer: Harlow, UK, 1872. 
57. Schumpeter, J.A. The Theory of Economic Development: An Inquiry into Profits, Capital, Credit, Interest, and the Business Cycle (1912/1934); Transaction Publishers: Piscataway, NJ, USA, 1982; Volume 1, p. 244.

58. Rotter, J.B. Generalized expectancies for internal versus external control of reinforcement. Psychol. Monogr. Gen. Appl. 1966, 80, 1. [CrossRef]

59. Neisser, U. Cognitive Psychology; Appleton-Century-Crofts: New York, NY, USA, 1967.

60. Kirton, M. Adaptors and innovators: A description and measure. J. Appl. Psychol. 1976, 61, 622. [CrossRef]

61. Phillips, L.D.; Wright, C. Cultural differences in viewing uncertainty and assessing probabilities. In Decision Making and Change in Human Affairs; Springer: Berlin/Heidelberg, Germany, 1977; pp. 507-519.

62. Brockhaus, R.H. The psychology of the entrepreneur. In University of Illinois at Urbana-Champaign's Academy for Entrepreneurial Leadership Historical Research Reference in Entrepreneurship; Urbana-Champaign: Champaign County, IL, USA, 1982.

63. Begley, T.M.; Boyd, D.P. Psychological characteristics associated with performence in entrepreneurial firms and smaller businesses. J. Bus. Ventur. 1987, 2, 79-93. [CrossRef]

64. Mitton, D.G. The compleat entrepreneur. Entrep. Theory Pract. 1989, 13, 9-20. [CrossRef]

65. Shaver, K.G.; Scott, L.R. Person, process, choice: The psychology of new venture creation. Entrep. Theory Pract. 1992, 16, 23-46. [CrossRef]

66. Bird, B.J. The operation of intentions in time: The emergence of the new venture. Entrep. Theory Pract. 1992, 17, 11-20. [CrossRef]

67. Gartner, W.B.; Bird, B.J.; Starr, J.A. Acting as if: Differentiating entrepreneurial from organizational behavior. Entrep. Theory Pract. 1992, 16, 13-32. [CrossRef]

68. Venkataraman, S.; MacMillan, I.; McGrath, G.; Sexton, D. Progress in research on corporate venturing. Manag. Sci. 1990, $30,9$.

69. Krueger, N. The impact of prior entrepreneurial exposure on perceptions of new venture feasibility and desirability. Entrep. Theory Pract. 1993, 18, 5-21. [CrossRef]

70. McLain, D.L. The MSTAT-I: A new measure of an individual's tolerance for ambiguity. Educ. Psychol. Meas. 1993, 53, 183-189. [CrossRef]

71. Kirzner, I.M. Creatividad, Capital y Justicia Distributiva; Union Editorial: New York, NY, USA, 1995.

72. Venkataraman, S.; Katz, J.; Brockhaus, R. Advances in Entrepreneurship, Firm Emergence, and Growth; JAI Press: Greenwich, CT, USA, 1997; Volume 3, pp. 119-138.

73. Clement, S. The self-efficacy expectations and occupational preferences of females and males. J. Occup. Psychol. 1987, 60, 257-265. [CrossRef]

74. McGrath, R.G. Falling forward: Real options reasoning and entrepreneurial failure. Acad. Manag. Rev. 1999, 24, 13-30. [CrossRef]

75. Shepherd, D.A.; Douglas, E.J.; Shanley, M. New venture survival: Ignorance, external shocks, and risk reduction strategies. J. Bus. Ventur. 2000, 15, 393-410. [CrossRef]

76. Sarasvathy, S.D. Causation and effectuation: Toward a theoretical shift from economic inevitability to entrepreneurial contingency. Acad. Manag. Rev. 2001, 26, 243-263. [CrossRef]

77. Lüthje, C.; Franke, N. The 'making' of an entrepreneur: Testing a model of entrepreneurial intent among engineering students at MIT. REd Manag. 2003, 33, 135-147.

78. Shane, S.A. A General Theory of Entrepreneurship: The Individual-Opportunity Nexus; Edward Elgar Publishing: Cheltenham, UK, 2003.

79. Shepherd, D.A. Learning from business failure: Propositions of grief recovery for the self-employed. Acad. Manag. Rev. 2003, 28, 318-328. [CrossRef]

80. Ucbasaran, D.; Westhead, P.; Wright, M. Business ownership experience, information search and opportunity identification: A research note. In Proceedings of the Academy of Management Meeting, Seattle, WA, USA, 3-6 August 2003.

81. Chen, G.; Gully, S.M.; Eden, D. General self-efficacy and self-esteem: Toward theoretical and empirical distinction between correlated self-evaluations. J. Organ. Behav. Int. J. Ind. Occup. Organ. Psychol. Behav. 2004, 25, 375-395. [CrossRef]

82. Gupta, V.; MacMillan, I.C.; Surie, G. Entrepreneurial leadership: Developing and measuring a cross-cultural construct. J. Bus. Ventur. 2004, 19, 241-260. [CrossRef]

83. Minniti, M. Entrepreneurship and network externalities. J. Econ. Behav. Organ. 2005, 57, 1-27. [CrossRef]

84. Politis, D. The process of entrepreneurial learning: A conceptual framework. Entrep. Theory Pract. 2005, 29, 399-424. [CrossRef]

85. Segal, G.; Borgia, D.; Schoenfeld, J. The motivation to become an entrepreneur. Int. J. Entrep. Behav. Res. 2005, 77, 42-57. [CrossRef]

86. De Carolis, D.M.; Saparito, P. Social capital, cognition, and entrepreneurial opportunities: A theoretical framework. Entrep. Theory Pract. 2006, 30, 41-56. [CrossRef]

87. Goel, S.; Karri, R. Entrepreneurs, effectual logic, and over-trust. Entrep. Theory Pract. 2006, 30, 477-493. [CrossRef]

88. Schindehutte, M.; Morris, M.; Allen, J. Beyond achievement: Entrepreneurship as extreme experience. Small Bus. Econ. 2006, 27, 349-368. [CrossRef]

89. Alvarez, S.A.; Barney, J.B. Discovery and creation: Alternative theories of entrepreneurial action. Strateg. Entrep. J. 2007, 1, 11-26. [CrossRef]

90. Tornikoski, E.T.; Newbert, S.L. Exploring the determinants of organizational emergence: A legitimacy perspective. J. Bus. Ventur. 2007, 22, 311-335. [CrossRef] 
91. Anderson, A.R.; Smith, R. The moral space in entrepreneurship: An exploration of ethical imperatives and the moral legitimacy of being enterprising. Entrep. Reg. Dev. 2007, 19, 479-497. [CrossRef]

92. Rauch, A.; Frese, M. Born to be an entrepreneur? Revisiting the personality approach to entrepreneurship. In The Psychology of Entrepreneurship; Psychology Press: Hove, UK, 2007; pp. 41-65.

93. Klein, P.G. Opportunity discovery, entrepreneurial action, and economic organization. Strateg. Entrep. J. 2008, 2, 175-190. [CrossRef]

94. Politis, D. Does prior start-up experience matter for entrepreneurs' learning? A comparison between novice and habitual entrepreneurs. J. Small Bus. Enterp. Dev. 2008, 15, 472-489. [CrossRef]

95. McGee, J.E.; Peterson, M.; Mueller, S.L.; Sequeira, J.M. Entrepreneurial self-efficacy: Refining the measure. Entrep. Theory Pract. 2009, 33, 965-988. [CrossRef]

96. Politis, D.; Gabrielsson, J. Entrepreneurs' attitudes towards failure: An experiential learning approach. Int. J. Entrep. Behav. Res. 2009, 5, 364-383. [CrossRef]

97. Rutherford, M.W.; Buller, P.F.; Stebbins, J.M. Ethical considerations of the legitimacy lie. Entrep. Theory Pract. 2009, 33, 949-964. [CrossRef]

98. Drnovšek, M.; Wincent, J.; Cardon, M.S. Entrepreneurial self-efficacy and business start-up: Developing a multi-dimensional definition. Int. J. Entrep. Behav. Res. 2010, 16, 329-348. [CrossRef]

99. Fillis, I.; Rentschler, R. The role of creativity in entrepreneurship. J. Enterprising Cult. 2010, 18, 49-81. [CrossRef]

100. Miao, Q.; Liu, L. A psychological model of entrepreneurial decision making. Soc. Behav. Personal. Int. J. 2010, 38, 357-363. [CrossRef]

101. Peris Bonet, F.J.; Peris-Ortiz, M.; Gil-Pechuan, I. Integrating transaction cost economics and the resource-based view in services and innovation. Serv. Ind. J. 2010, 30, 701-712. [CrossRef]

102. Sarri, K.K.; Bakouros, I.L.; Petridou, E. Entrepreneur training for creativity and innovation. J. Eur. Ind. Train. 2010, 34, 270-288. [CrossRef]

103. Cope, J. Entrepreneurial learning from failure: An interpretative phenomenological analysis. J. Bus. Ventur. 2011, 26, 604-623. [CrossRef]

104. Sommer, L.; Haug, M. Intention as a cognitive antecedent to international entrepreneurship-Understanding the moderating roles of knowledge and experience. Int. Entrep. Manag. J. 2011, 7, 111-142. [CrossRef]

105. Welpe, I.M.; Spörrle, M.; Grichnik, D.; Michl, T.; Audretsch, D.B. Emotions and opportunities: The interplay of opportunity evaluation, fear, joy, and anger as antecedent of entrepreneurial exploitation. Entrep. Theory Pract. 2012, 36, 69-96. [CrossRef]

106. Alvarez, S.A.; Barney, J.B.; Anderson, P. Forming and exploiting opportunities: The implications of discovery and creation processes for entrepreneurial and organizational research. Organ. Sci. 2013, 24, 301-317. [CrossRef]

107. Matlay, H.; Dinis, A.; do Paço, A.; Ferreira, J.; Raposo, M.; Rodrigues, R.G. Psychological characteristics and entrepreneurial intentions among secondary students. Educ. Train. 2013, 55, 763-780.

108. Kreiser, P.M.; Marino, L.D.; Kuratko, D.F.; Weaver, K.M. Disaggregating entrepreneurial orientation: The non-linear impact of innovativeness, proactiveness and risk-taking on SME performance. Small Bus. Econ. 2013, 40, 273-291. [CrossRef]

109. Ahlin, B.; Drnovšek, M.; Hisrich, R.D. Entrepreneurs' creativity and firm innovation: The moderating role of entrepreneurial self-efficacy. Small Bus. Econ. 2014, 43, 101-117. [CrossRef]

110. Alvarez, S.A.; Barney, J.B. Entrepreneurial opportunities and poverty alleviation. Entrep. Theory Pract. 2014, 38, 159-184. [CrossRef]

111. Gundry, L.K.; Ofstein, L.F.; Kickul, J.R. Seeing around corners: How creativity skills in entrepreneurship education influence innovation in business. Int. J. Manag. Educ. 2014, 12, 529-538. [CrossRef]

112. Aldrich, H.E.; Martinez, M.A. Why aren't entrepreneurs more creative? Conditions affecting creativity and innovation in entrepreneurial activity. In The Oxford Handbook of Creativity, Innovation, and Entrepreneurship; Oxford University Press: Oxford, UK, 2015; pp. 445-456.

113. Cacciotti, G.; Hayton, J.C. Fear and entrepreneurship: A review and research agenda. Int. J. Manag. Rev. 2015, 17, 165-190. [CrossRef]

114. Chatterjee, N.; Das, N. Key psychological factors as predictors of entrepreneurial success: A conceptual framework. Acad. Entrep. J. 2015, 21, 102.

115. Davidsson, P. Entrepreneurial opportunities and the entrepreneurship nexus: A re-conceptualization. J. Bus. Ventur. 2015, 30, 674-695. [CrossRef]

116. Edwards-Schachter, M.; García-Granero, A.; Sánchez-Barrioluengo, M.; Quesada-Pineda, H.; Amara, N. Disentangling competences: Interrelationships on creativity, innovation and entrepreneurship. Think. Skills Creat. 2015, 16, 27-39. [CrossRef]

117. Gielnik, M.M.; Spitzmuller, M.; Schmitt, A.; Klemann, D.K.; Frese, M. "I put in effort, therefore I am passionate": Investigating the path from effort to passion in entrepreneurship. Acad. Manag. J. 2015, 58, 1012-1031. [CrossRef]

118. Holland, D.V.; Garrett, R.P. Entrepreneur start-up versus persistence decisions: A critical evaluation of expectancy and value. Int. Small Bus. J. 2015, 33, 194-215. [CrossRef]

119. Maine, E.; Soh, P.H.; Dos Santos, N. The role of entrepreneurial decision-making in opportunity creation and recognition. Technovation 2015, 39, 53-72. [CrossRef] 
120. Brännback, M.; Carsrud, A.L. Understanding entrepreneurial cognitions through the lenses of context. In A Research Agenda for Entrepreneurship and Context; Edward Elgar Publishing: Cheltenham, UK, 2016; pp. 16-27.

121. Hsiao, C.; Lee, Y.H.; Chen, H.H. The effects of internal locus of control on entrepreneurship: The mediating mechanisms of social capital and human capital. Int. J. Hum. Resour. Manag. 2016, 27, 1158-1172. [CrossRef]

122. Ismail, I.; Husin, N.; Rahim, N.A.; Kamal, M.H.M.; Mat, R.C. Entrepreneurial success among single mothers: The role of motivation and passion. Procedia Econ. Financ. 2016, 37, 121-128. [CrossRef]

123. Liñán, F.; Moriano, J.A.; Jaén, I. Individualism and entrepreneurship: Does the pattern depend on the social context? Int. Small Bus. J. 2016, 34, 760-776. [CrossRef]

124. Cannavacciuolo, L.; Iandoli, L.; Ponsiglione, C.; Zollo, G. Learning by failure vs learning by habits. Int. J. Entrep. Behav. Res. 2017, 23, 524-546. [CrossRef]

125. Gaglio, C.M.; Winter, S. Entrepreneurial alertness and opportunity identification: Where are we now? In Revisiting the Entrepreneurial Mind; Springer: Berlin/Heidelberg, Germany, 2017; pp. 339-358.

126. Invernizzi, A.C.; Menozzi, A.; Passarani, D.A.; Patton, D.; Viglia, G. Entrepreneurial overconfidence and its impact upon performance. Int. Small Bus. J. 2017, 35, 709-728. [CrossRef]

127. Knopf, L.R.; Stone, G.A.; Winston, B.E. Profiles of entrepreneurs: Discriminant and cluster analyses of the Romans 12 motivational gifts and locus of control as predictors of entrepreneurs. J. Biblic. Integr. Bus. 2017, 20.

128. Kuratko, D.F.; Fisher, G.; Bloodgood, J.M.; Hornsby, J.S. The paradox of new venture legitimation within an entrepreneurial ecosystem. Small Bus. Econ. 2017, 49, 119-140. [CrossRef]

129. Leitch, C.M.; Volery, T. Entrepreneurial leadership: Insights and directions. Int. Small Bus. J. 2017, 35, 147-156. [CrossRef]

130. McGee, J.E.; Peterson, M. The long-term impact of entrepreneurial self-efficacy and entrepreneurial orientation on venture performance. J. Small Bus. Manag. 2019, 57, 720-737. [CrossRef]

131. Bernoster, I.; Rietveld, C.A.; Thurik, A.R.; Torrès, O. Overconfidence, optimism and entrepreneurship. Sustainability 2018, 10, 2233. [CrossRef]

132. Stroe, S.; Parida, V.; Wincent, J. Effectuation or causation: An fsQCA analysis of entrepreneurial passion, risk perception, and self-efficacy. J. Bus. Res. 2018, 89, 265-272. [CrossRef]

133. Friedman, M.; Rosenman, R. Type A Behavior and Your Heart, Fawcett, Greenwich, CT. In Friedman Type A Behavior and Your Heart 1974; Taylor \& Francis: Milton, UK, 1974.

134. Sánchez, A.V.; Ruiz, M.P. Practicum y evaluación de competencias. Profesorado. Rev. De Currículum Y Form. De Profr. $2004,8,0$.

135. Lumpkin, G.T.; Dess, G.G. Clarifying the entrepreneurial orientation construct and linking it to performance. Acad. Manag. Rev. 1996, 21, 135-172. [CrossRef]

136. Melville, N.; Kraemer, K.; Gurbaxani, V. Information technology and organizational performance: An integrative model of IT business value. MIS Quartely 2004, 28, 283-32 . [CrossRef]

137. Ahmed, I.; Ali, G.; Ramzan, M. Leader and organization: The impetus for individuals' entrepreneurial orientation and project success. J. Glob. Entrep. Res. 2014, 4, 1-11. [CrossRef]

138. Anderson, B.S.; Kreiser, P.M.; Kuratko, D.F.; Hornsby, J.S.; Eshima, Y. Reconceptualizing entrepreneurial orientation. Strateg. Manag. J. 2015, 36, 1579-1596. [CrossRef]

139. Barclay, C.; Osei-Bryson, K.M. Project performance development framework: An approach for developing performance criteria \& measures for information systems (IS) projects. Int. J. Prod. Econ. 2010, 124, 272-292.

140. Atkinson, R. Project management: Cost, time and quality, two best guesses and a phenomenon, its time to accept other success criteria. Int. J. Proj. Manag. 1999, 17, 337-342. [CrossRef]

141. Glass, R.L. IT failure rates-70\% or 10-15\%? IEEE Softw. 2005, 22, 110-112. [CrossRef]

142. Agarwal, N.; Rathod, U. Defining 'success' for software projects: An exploratory revelation. Int. J. Proj. Manag. 2006, 24, 358-370. [CrossRef]

143. DeVellis, R.F. Scale Development: Theory and Applications; Sage Publications: Thousand Oaks, CA, USA, 2016 ; Volume 26.

144. Géron, A. Hands-on Machine Learning with Scikit-Learn, Keras, and TensorFlow: Concepts, Tools, and Techniques to Build Intelligent Systems; O'Reilly Media: Sebastopol, CA, USA, 2019.

145. Delmar, F.; Davidsson, P. Where do they come from? Prevalence and characteristics of nascent entrepreneurs. Entrep. Reg. Dev. 2000, 12, 1-23. [CrossRef]

146. Reynolds, P.D.; Carter, N.M.; Gartner, W.B.; Greene, P.G. The prevalence of nascent entrepreneurs in the United States: Evidence from the panel study of entrepreneurial dynamics. Small Bus. Econ. 2004, 23, 263-284. [CrossRef]

147. Lichtenstein, B.B.; Carter, N.M.; Dooley, K.J.; Gartner, W.B. Complexity dynamics of nascent entrepreneurship. J. Bus. Ventur. 2007, 22, 236-261. [CrossRef]

148. Wagner, J. Are young and small firms hothouses for nascent entrepreneurs? Evidence from German micro data. In Evidence from German Micro Data (January 2004); Econstor by ZBW: Hamburg, Germany, 2004.

149. Singh, R.P.; Hills, G.E.; Lumpkin, G.; Hybels, R.C. The entrepreneurial opportunity recognition process: Examining the role of self-perceived alertness and social networks. In Academy of Management Proceedings; Academy of Management: Briarcliff Manor, NY, USA, 1999; Volume 1999, pp. G1-G6.

150. Liñán, F.; Santos, F.J. Does social capital affect entrepreneurial intentions? Int. Adv. Econ. Res. 2007, 13, 443-453. [CrossRef] 
151. Boyd, N.G.; Vozikis, G.S. The influence of self-efficacy on the development of entrepreneurial intentions and actions. Entrep. Theory Pract. 1994, 18, 63-77. [CrossRef]

152. Erikson, T. Entrepreneurial capital: The emerging venture's most important asset and competitive advantage. J. Bus. Ventur. 2002, 17, 275-290. [CrossRef] 